\title{
Public Statues and Second-Class Citizens: The Spatial Politics of Romani Visibility in Interwar Budapest
}

\section{Árpád Bak}

\author{
arpadbak@gmail.com
}

ORCID: https://orcid.org/0000-0003-1794-7818

Árpád Bak is working on a doctoral thesis for submission to the Doctoral Program in Film, Media and Contemporary Culture at Eötvös Loránd University, Budapest, Hungary. His research interests focus on the politics of representation in contemporary art and urban spaces. He holds a degree in English language and literature from the University of Debrecen, Hungary. In addition to a career in journalism, he volunteered and worked for Romani and anti-discrimination organizations in Hungary, including the European Roma Cultural Foundation and Romedia Foundation. In 2018, he was junior visiting researcher at the Romani Studies Program at Central European University, Budapest.

\section{Critical}

Romani Studies 


\section{Abstract}

In what might be called an extreme form of tokenism, memory sites devoted to the figures of outstanding Romani musicians, including public statues, began to appear in public urban spaces in fin-de-siècle and interwar Hungary amid the growing oppression of Roma by authorities. This article investigates, by focusing on case studies from Budapest in the interwar period, how public representations of Roma in the cultural spaces of dominant society, though apparently inscribing diversity in the national narrative, were involved in the hegemonic practices of the time. The complexities of the interplay between inclusion in the symbolic realm and oppression in the social one are best illuminated when looking at the social and political uses of these urban landmarks.

\section{Keywords}

- Cultural oppression

- Memory sites

- Public statues

- Romani movement

- Interwar period

- Hungary 


\section{Introduction: A Dual Heritage of Policed Boundaries and Hegemonic Inclusion}

In contrast to legal and public discourse that criminalized itinerant Roma in early twentieth-century and interwar Hungary - alongside the oppression of increasingly broad segments of Romani society - the figure of the Romani bandleader (primás) was often celebrated, ${ }^{[1]}$ in part driven by the appropriation of "Hungarian-Gypsy music" [2] by Hungarian nationalism in these periods. Yet Romani musicians were also subject to a number of hegemonic practices by dominant society, thus it can be claimed that the experience of this professional group was shaped by a form of discrimination that advocated an intraethnic hierarchy among Roma. This externally imposed stratification divided the Romani community into two major parts, based on whether their members or ancestors thereof arrived to Hungary with the first wave of Romani migration within Europe in the Middle Ages or with the second wave in the nineteenth century after the abolition of Romani slavery in the Romanian principalities of Moldavia and Wallachia. The separate paths of the histories of these groups were reflected in differences in domains such as lifestyle, language use, traditional occupations or relations with dominant society.

Hungary's community of Romani musicians formed mostly within the first, settled group of Roma. Unlike in the cases of other countries in Central and Eastern Europe, the figure of the Romani musician came to be included among the symbols of Hungarian national culture in the nineteenth-century

\footnotetext{
1 This celebration extended to both official and popular forms of recognition in the examined period. Examples for the former include Romani bandleaders Béla Radics (1867-1930), Imre Magyari Sr. (1864-1929), and Imre Magyari Jr. (1894-1940) receiving the award of the Hungarian governor, the Signum Laudis, in 1926, 1927, and in 1935, respectively (Nyírvidék 1927; Ujság 1927c; Sz. N. 1935). The capital city also granted honorary graves in Kerepesi Road Cemetery to Kálmán Balázs (1835-1900) (Pesti Napló 1900), Béla Radics (Magyar Országos Tudósitó 1930d), Imre Magyari Jr. (Népszava 1940), and Laci Rácz the 36th (1867-1943) (Ujság 1943), building on precedents in the nineteenth century (Fövárosi Lapok 1895). The celebrity status of the Romani bandleader in society is reflected, among others, in crowds of thousands - in Radics's case one of 100,000 - attending these musicians' funerals (Budapesti Hirlap 1885b; Az Est 1926; Magyarország 1926; Magyar Országos Tudósitó 1930c; Pesti Napló 1934), the often illustrated press coverage (Tolnai Világlapja 1925; Az Est 1926; Pesti Napló 1926; Az Est 1930; Pesti Napló 1934; Farkas 1940; Pesti Hirlap 1943) and cinematic reportage (Magyar Film Iroda Rt. 1930) of these events, or of the jubilees of these figures (T. 1924; Magyar Film Iroda Rt. 1926; Gy. S. 1930), and interviews with them in the press (Az Ujság 1910; Ormos 1925; Lázár 1926; Nyírvidék 1927; Lukács 1929; Ujság 1929c; B. L. 1930; K. K. 1934; Gosztonyi 1935; Sz. N. 1935; Ujság 1937a). In an obituary written for Antal Kóczé (1872-1926), Gyula Krúdy notes: "the public opinion, busy with tale-telling, legends, knows almost more about Gypsy bandleaders [cigányprímás] famous enough than even about our notable statesmen" ([1926] 1971, 95). The information regarding the governor's award is credited to personal communication with Csaba Csapó on 28 July 2018.
}

2 Following Lynn M. Hooker's terminology, by "Hungarian-Gypsy music" this paper refers to early forms of popular music in Hungary that were typically performed by Romani musicians from the late eighteenth century onward, such as verbunkos, csárdás and, as a nineteenth-century addition, magyar nóta (Hungarian song). These genres are thought to have been derived from local non-Romani folk music traditions, adapted partly by Romani musicians themselves for their non-Romani audiences. Romani musicians also authored several new music pieces in these styles, and this music tradition also became a key influence for the development of a national school of art music by nineteenth-century Hungarian non-Romani composers such as Franz Liszt, Ferenc Erkel, and Mihály Mosonyi (Loya 2011, 64). "Hungarian-Gypsy music," often called “Gypsy music” (cigányzene) in common language, is differentiated from Romani folk music, which was practiced within Romani communities and developed independently from the former music tradition (Sárosi 1971, 20-30). 
popular imagination, both domestically and internationally (cf. Piotrowska 2013, 13-53), as performer of a folk-derived instrumental dance music, with a political subtext for local audiences. While its Western consumers were fascinated by "Hungarian-Gypsy music" for its exoticism (Hungarian "Gypsy bands" toured Western Europe from the second half of the nineteenth century [Sárosi 1971, 122]), partly defined by the unique performance style of the "Gypsy band" (Loya 2011, 61), domestically it formed part of a patriotic tradition in the arts, associated with the memory of anti-Habsburg wars in the late seventeenth and early eighteenth centuries. ${ }^{[3]}$ The musical and poetic heritage that emerged in the wake of these early, nobility-led independence struggles of the (still nascent) nation, especially the war of independence led by Prince Ferenc Rákóczi II (1703-1711), remained an important reference point for subsequent nationalist movements. As a consequence, a representational tradition in Hungary came to regard Romani musicians - who had a fundamental role in maintaining the musical part of this heritage since the late eighteenth century (Sárosi 1971, 59) - as custodians of the national spirit, often contrasted in public discourse with nonindigenous, itinerant Roma from Moldavia and Wallachia, who were labeled as outsiders. ${ }^{[4]}$

However, pieces of legislation that were passed to forcibly settle itinerant Roma - and to relegate them to the status of second-class citizens - included measures that could be applied to any Roma in some contexts. For example, a 1916 decree of the interior minister (15.000/1916. B.M. eln.) on "wandering (tent-dwelling) Gypsies" [kóbor (sátoros) cigányok], ${ }^{[5]}$ ordered law enforcement agencies, among other stipulations, to send or force any Roma home who happened to be away from their place of residence "without sufficient justification" (15.000/1916. B.M. eln., 440; see also Bársony [2004] 2007, 29-30), leaving what counts as justified up to the judgment of those applying the decree.

\footnotetext{
3 For discussions of how internal and external constructions of Hungarian national culture made use of "Hungarian-Gypsy music" and the figure of the Romani musician in the nineteenth century, see: Jonathan Bellman, The Style Hongrois in the Music of Western Europe (Boston: Northeastern University Press, 1993); Lynn M. Hooker, Redefining Hungarian Music from Liszt to Bartók (New York: Oxford University Press, 2013); Shay Loya, Liszt's Transcultural Modernism and the Hungarian-Gypsy Tradition (Rochester: University of Rochester Press, 2011); Anna G. Piotrowska, Gypsy Music in European Culture: From the Late Eighteenth to the Early Twentieth Centuries (Boston: Northeastern University Press, 2013).
}

4 For example, in an opinion piece in the 6 August 1907 issue of the daily Pesti Hirlap, Kálmán Porzsolt, former director of People’s Theater (Népszínház), Budapest, went as far as calling for the extermination of "the wandering Vlach Gypsy" (vándor oláh cigány) (10), citing the crimes committed against indigenous societies outside Europe by Western colonizing powers as a model to follow, while he simultaneously praised "the Hungarian Gypsy [magyar cigány], who often make brilliant Gypsy musicians [cigány zenészek]" and thus need to be "patronized and educated" (ibid.). He also credits the latter group, a "half-blood Hungarian tribe" (félvér magyar néptörzs) (ibid.), for its service in preserving the national musical heritage: "If Hungarian musician Gypsies [magyar muzsikus cigányok] hadn’t sustained, with their geniality and national sentiment, Hungarian musical motifs, the Hungarian sentiment in song and music, from where would we collect that together now?" (ibid.)

5 The regulation mandated to settle and register itinerant Roma and called for seizing their belongings, issuing a "Gypsy identification card" (cigányigazolvány) (15.000/1916. B.M. eln., 443) for them, marking their skins with specially arranged vaccine scars as a proof of having been registered, obligating them to compensate for their accommodation and sustenance costs by public work, banning them from keeping harness animals or from leaving their village of residence without police permission and made it possible to send those resisting to state-run labor camps (439-447). The decree defined itinerant Roma rather broadly, including in this category any Roma who could not prove to have a permanent address, regardless whether they had the means to sustain themselves (439-440). These measures stayed in effect during the interwar period. 
Some measures against Roma in the interwar period were open about including, under some conditions, Romani musicians among their target groups. In April 1939, deputy-lieutenant of Pest County László Endre, notorious for his racial preservationist views and later activities as a Nazi collaborator, ${ }^{[6]}$ ordered the registration, in his jurisdiction, of "all settled Vlach (traveling) Gypsies [oláh (vándor) cigányok] and those musician Gypsies [zenész cigányok] who reside in Gypsy quarters [cigány rész] and who cannot support themselves from their music" (quoted by Purcsi Barna [2004] 2007, 72) ${ }^{[7]}$ as additional provisions to the measures of the decree of the interior minister 257.000/1928. B.M., which introduced annual roundups and population counts of itinerant Roma (1026-1027), implemented in the form of “Gypsy raids” (cigányrazzia) (Purcsi Barna [2004] 2007, 50-51, 69-83). Endre’s 1939 order to double the number of these raids in his area of control (70) and to take action against the most vulnerable, financially troubled Romani musicians came at a time when the livelihood of this profession was severely compromised by the growing popularity of jazz, as widely discussed in the press of the time. ${ }^{[8]}$

Not only unemployed Romani musicians could become objects of discrimination by authorities, but sometimes any member of this professional group. At an August 1939 meeting of the public administration committee of Budapest, Béla Usetty, MP of the right-wing United Municipal Civic Party (Egységes Községi Polgári Párt), urged police measures to preclude Romani musicians from having evening discussions on benches along the Danube Promenade, a pedestrian area on the riverbank. Usetty claimed that "guests [of the nearby Grand Hotel Hungária] often complain and, moreover, leave the hotel" (Magyar Országos Tudósító 1939, 109) because of the Romani presence, among other reasons. Invoking a common trope of antigypsyism of the time, Usetty argued that such a forced ethnic homogenization of the area was necessary on economic grounds, to protect the local tourism industry. Paradoxically, the same economic interests led Budapest restaurants to provide "Hungarian-Gypsy music" to their guests ${ }^{[9]}$ and also led the state to include this form of music in international promotions of the country during the ultranationalist Horthy regime (1920-1944), such as a campaign reportedly advertising Budapest as the "city of love and Gypsy music" (Kolcov 1928; see also Vari 2012, 728). ${ }^{[10]}$

6 As chief magistrate of the Gödöllö district (1923-1937) and deputy lieutenant of Pest County (1938-1944), he voluntarily introduced measures against the Jewish and Romani communities, alongside his involvement in a number of far-right political organizations and parties (Purcsi Barna [2004] 2007, 63-84). Later, in various roles (state secretary, government commissioner) in two of the successive puppet governments during the occupation of Hungary by Nazi Germany (1944-1945), he played an active role in the ghettoization and deportation of Jewish Hungarians (84-85).

7 The Hungarian translations in square brackets are taken from the original, Hungarian version of the text (quoted in Purcsi Barna 2004, 49).

8 Between the 1920s and the mid-1930s the dominant discourse on "Gypsy music" in the mainstream press in Hungary focused on the harsh social realities of Romani musicians created by the new public acclaim for jazz, especially as made visible by the activities of the National Association of Hungarian Gypsy Musicians (Magyar Cigányzenészek Országos Egyesülete, MCOE), cf. Pesti Hirlap 1922; Stób 1926; Ujság 1927d, 1927e; D. I. 1928; Esti Kurir 1928; Magyarország 1928; Sági 1928; Somogyi 1928; 8 Órai Ujság 1934; Esti Kurir 1934; Budapesti Hirlap 1936; Magyarság 1936b.

9 Upon Romani bandleader Imre Magyari's death in 1940, the daily Pesti Hirlap wrote: "Magyari played at [the Grand Hotel] Hungária, and if there were a great award for advancing tourism, it could have ornamented his wide chest” (Farkas 1940, 12).

10 Furthermore, both the 1936 and 1943 statutes of MCOE list among the aims of the organization "the more efficient advancement of the tourism interests related to the fame of Hungarian Gypsy musicians [cigányzenészség]” (MCOSz 1936, 1; MCOE 1943, 3). 
Despite the high level of public recognition of Romani musicians in the interwar period, many other cases attest that they were also subject to legal, institutional, and social discrimination, both in Hungary and abroad. The period saw oppressive pieces of legislation and actions against multiple segments of the Romani community, extending far beyond the forced abolishment of itinerancy and well before the German occupation of the country in March 1944. A comprehensive summary of these actions is beyond the scope of this article. ${ }^{[1]}$ A striking example, however, is that the central investigative agency of the Hungarian Royal Gendarmerie started to build a countrywide "Gypsy registry” [cigány nyilvántartás] in 1940, with the purpose of collecting the personal data of "all Gypsies [cigányok] living in Hungary [...] whether they have committed a crime or not," as Pál Kaposi, sergeant-major of the authority, disclosed in the biweekly Csendörségi Lapok (1941, 327), "because," he added, "they can commit one at any time" (ibid.). In a further overt display of antigypsyist prejudices, Kaposi also asserted that "at the moment of identity check, the Gypsy [cigány] may be the most innocent, they may be working peacefully, like hundreds of other decent people who earn a living through work, but it does not warrant that they have not committed many and serious crimes before" (327), urging all local units of the gendarmerie in the country to automatically treat all Roma residing in or passing through their district as suspects of crime and take their fingerprints, a practice that Kaposi claimed was already followed by many units (326).

Even if, simultaneously, the figure of the Romani bandleader earned the status of celebrity in this period, yielding a proliferation of celebrating representations, these eulogizing gestures went hand in hand with antigypsyist stereotypes in the press and the cultural production of the time, often also projected on the figure of the Romani musician (see, e.g., Kellér 1926). The National Association of Hungarian Gypsy Musicians (Magyar Cigányzenészek Országos Egyesülete, MCOE), or its officials, responded to some of these offensive portrayals in the form of opinion pieces (cf. Járosi 1930; Magyar Cigányzenészek Lapja 1927, 1930) and, in one occasion, by filing a libel case against music critic Margit Prahács for her racist insults against Roma in the journal Napkelet, in which she urged the purification of Hungarian music culture from Romani influences (Magyar Országos Tudósitó 1930a).

With a clear awareness of this hostile administrative, ideological, and legal environment for Roma, including Romani musicians, in the interwar period, this article aims to address the alliance of nationalism and the cult of "Hungarian-Gypsy music" in the country at the time, focusing on the effects of this conjuncture on the urban heritage environment. Despite a shift to an ethnic concept of the nation after the First Word War (Trencsényi 2012, 87-90), with antecedents going back to the 1890s (85-86),

11 For more detailed surveys of legislations related to Roma in pre- and interwar Hungary, see: János Bársony and Ágnes Daróczi, eds., Pharrajimos: The Fate of the Roma During the Holocaust, Translated by Gábor Komáromy (New York: International Debate Education Association, [2004] 2007); László Karsai, A cigánykérdés Magyarországon 1919-1945: út a cigány Holocausthoz (The Gypsy question in Hungary 1919-1945: The path to the Gypsy Holocaust) (Budapest: Cserépfalvi, 1992); Barna Mezey and István Tauber, "A magyarországi cigányság helyzetének rendezését célzó jogi szabályozás egyes kérdéseiről” (On certain questions of the legal regulation aiming to settle the condition of Gypsy people in Hungary) Acta Facultatis Politico-Juridicae Universitas Scientiarium Budapestiensis de L. Eötvös Nominatae No 23: 211-233 (1980); László Pomogyi, Cigánykérdés és cigányügyi igazgatás a polgári Magyarországon (The Gypsy question and the administration of Gypsy issues in bourgeois Hungary) (Budapest: OsirisSzázadvég, 1995). The author of this article finds it unfortunate that some of these works use the term cigánykérdés (Gypsy question) in their titles, uncritically reproducing the vocabulary of oppressive administrative regimes. 
"Hungarian-Gypsy music," as a form of popular music, remained a symbol for nationalism after the war, serving as a source of nostalgia for the prewar Kingdom of Hungary, an empire with hegemony over large parts of the region. This newly assumed cultural meaning of the music style warranted its continued appropriation by nationalist politics, simultaneously defined in the period by the contradictory ambitions of irredentism, on the one hand, and the creation of a homogeneous nation state, on the other (cf. Barany 1969, 283-299; Trencsényi 2012, 88-120). Additionally, "Hungarian-Gypsy music" continued to enjoy political support in the entertainment industry during the Horthy regime as a cultural protectionist strategy against the influence of jazz (Hajnáczky 2019, 24-38). ${ }^{[12]}$

The emergence of the figure of the Romani musician as an "Orientalist-cum-nationalist icon" (Hooker 2013 , 16) also inaugurated a minor tendency in sculpture in late nineteenth- and early twentiethcentury Hungary that defied, in some respects at least, former traditions of representing Roma. As part of this phenomenon, a series of four public statues made between 1889 and $1932^{[13]}$ marked a turn in representational practices not only by being among the firsts in this branch of art to identify their Romani objects as individuals, ${ }^{[14]}$ but also by being located in urban environments that had a significance in the national imagination. The present article looks at the social and political history of four memory sites from interwar Budapest, including two such sculptural items (the public statues of Romani bandleaders János Bihari [László Vaszary, 1928, Figure 1] and Béla Radics [Lőrinc Siklódy, 1932, Figure 2]), a memorial plaque devoted to Bihari (1928, Figures 3-4), and a street named after Romani songwriter Pista Dankó, with the purpose of showing how these seemingly celebratory landmarks were implicated in the exclusionary and oppressive practices of their time.

When merely looking at their material configurations, these pieces of urban heritage can be deceptive, because they might evoke the type of inclusive heritage initiatives in late modern plural societies that Graham, Ashworth, and Tunbridge call "bridging heritage" $(2000,113)$ and describe as having "a bridging cultural relevance for both immigrant and host societies" (ibid.), thus requiring a "minimum amount of dissonance management" (ibid.). This article, however, claims that the examined memory sites and art objects are better comparable to public statuary in nineteenth- and early twentieth-century Latin

12 Opposite was the case of Hungarian art music from the 1910s. Marking a break with the first national school of classical music, a new generation of modernist composers, headed by Béla Bartók, propagated a turn to local folk music traditions for artistic inspiration in their "pure," unmediated forms (Hooker 2013, 95-153).

13 Antal Szécsi, Hungarian Music (János Bihari), 1889/1890; Ede Margó, Pista Dankó, 1912; László Vaszary, János Bihari, 1928 (Figure 1); Lőrinc Siklódy, Béla Radics, 1932 (Figure 2).

14 In Hungary, the first sculpture known to represent a specific Romani musician is Miklós Izsós 1869 small-scale terracotta study of Romani bandleader Ferkó Patikárus (1827-1870), who performed music in the Hungarian pavilion of the 1867 Paris Word Fair (Goda 1993, 50). Adolf Huszár is also known to have made a bust of Romani bandleader Pali Rácz (1815-1885) (Budapesti Hirlap 1885a, 4; Nagy 1990, 2), while Alajos Stróbl devoted one to actress Aranka Hegyi (1855-1906) - sometimes claimed to be of Romani origin by the press in her time (Sólymossy 1880, n.p.; Magyarország 1897, 7), on which she did not comment publicly (see Hegyi 1905) - in the 1880s (Csemer 1998, 2327), besides also using Hegyi as a model for an allegorical statue, embodying the Spanish dance fandango (Nagy 2004, 349). As these art objects are not known to have been permanently placed in public spaces (except for Stróbl's allegorical work, installed in Vigadó Concert Hall, Budapest in 1901 [Nagy 2004, 349-350]), they are considered here to be forerunners to the abovementioned tendency in sculpture. 
America, which also gave official recognition to ethnic and cultural pluralism in prominent urban spaces, but to a form of pluralism that was appropriated by nationalist projects led by dominant society. ${ }^{[15]}$

The statues of Bihari and Radics, though also located in urban spaces associated with national selfrepresentation, similarly failed to take on the abovementioned bridging function. To support this claim, this article demonstrates that the history of the social and political uses of these art objects uncover unequal power relations in society. In a contemporary context, commodified appropriations of multiculturalism in late capitalism offer an analogy, as such strategies of urban development produce urban centers that "[do] not require the physical presence of cultural 'others' - just that of their commodified symbols" (de Oliver 2001,244), although the motivation behind the heritage additions examined in this article was not related to the development of the tourism industry.

Though largely outside the scope of this analysis, the formal qualities of Bihari's and Radics's statues also betray oppressive social hierarchies. In this respect, a conspicuous feature of the abovementioned group of statues in fin-de-siècle and interwar Hungary is that all hold a violin in their hands, as also noted by some commentators of their time (Móra [1912a] 1964, 76-78; Móra 1912b, n.p.; Szegedi Napló 1912, 3; Tinódi 1928, 252). Amid calls in the public and administrative discourses of the Horthy regime to remove Romani musicians from public spaces if they were not performing music, this musical instrument easily turns into a sign of othering and subordination, marking the precondition for the represented figure to temporarily enter the spaces of dominant society. Not surprisingly, it was also in such a disempowered role that Roma could participate in the inauguration ceremonies and subsequent uses of urban memory sites related to Romani musicians in the examined period in Hungary.

\section{Muted Presences and Selective Narrative Framings}

A series of commemorative acts in Budapest in 1927 and 1928 to mark the centenary of late eighteenthand early nineteenth-century Hungarian Romani composer and bandleader János Bihari's death, a grassroots initiative driven mostly by the nationalist appropriation of Bihari's figure, ${ }^{[16]}$ came after a lengthy neglect of his memory, including the failure to erect a tomb monument for the internationally acclaimed musician. ${ }^{[17]}$ However, members of the Romani community, to which he belonged, including

15 Examples in Latin American urban heritage environments include Allegory of the Brazilian Empire, Rio de Janeiro, Brazil (Francisco Manuel Chaves Pinheiro, 1872), Monument to Cuauhtémoc, Mexico City, Mexico (Francisco Jiménez and Miguel Noreña, 1887), and Monument to Antonio Maceo, Havana, Cuba (Doménico Boni, 1916). For a discussion of how the Latin American ethos of diversity has been put to use for oppressive ends, see Marilyn Grace Miller, Rise and Fall of the Cosmic Race: The Cult of Mestizaje in Latin America (Austin: University of Texas Press, 2004).

16 From among Romani bandleaders, Bihari's figure was especially prone to be appropriated by dominant society, due to his status as a Hungarian composer known outside the country and to the military aspects of his career (to be discussed below in more details).

17 He was buried in the cemetery of Ferencváros (then an outer district of the city of Pest), which was closed down and razed in the second half of the nineteenth century and the fate of his grave is unknown (Tóth 1999, 9). It is known, however, that in 1862,35 years after his death, he still did not have a tomb memorial (Balla 1862). 
representatives of the organization of Romani musicians (MCOE), remained marginalized participants in planning and implementing these acts of commemoration, mostly confined to voiceless, subordinate roles at inauguration events. From the numerous programs of the 1927-1928 Bihari centennial, this section of the article focuses on those that involved interventions in the urban heritage landscape of Budapest, inscribing Bihari's memory into public spaces. The centenary entailed two such additions to the cultural map of the capital city, both of them near the historical center: on 13 October 1928, a memorial plaque (Figures 3-4) was placed on an apartment building in the ninth district (also known as Ferencváros) to mark the location of the composer's former home, to be followed a day later by the inauguration of his half-body bronze bust on Margaret Island, a park island on the Danube River.

The silencing of the Romani community in relation to these events began with "writing out" Roma from among the initiators of the effort to dedicate a plaque to Bihari in inner Ferencváros. On 22 April 1927, some leading dailies, running the same news agency item, claimed that "the Association of Gypsy Musicians" planned to install a memorial sign on the venue of Bihari's onetime residence the following month, and, as a preparatory measure, Romani bandleader Laci Rácz had already notified the mayor's office of a joint performance of 50 Romani musicians at the inauguration event (Friss Ujság 1927, Ujság 1927b). An article in the May 1927 issue of the association's newspaper, after discussing the failure to raise funds for the plaque, advocated for further efforts to establish a memory site for Bihari (Kun 1927, 1). However, in 1927 most press reports on the initiative - and in 1928 all of them - attributed the intention to install the plaque for Bihari simply to the "citizenry" (Tinódi 1928, 250), "society" (Budapesti Hirlap 1927b), or "social associations" (Budapesti Hirlap 1927b; Ujság 1927a; Pesti Napló 1927) of Ferencváros, usually associated in these texts with the names of Dezső Buday, MP of the radical right-wing Christian Municipal Party (Keresztény Községi Párt), and poorhouse director Ödön Pálos, neither of them known to be of Romani background. ${ }^{[18]}$ A news item in the 7 December 1927 issue of the weekly Független Budapest gave account of a visit by a committee, led by vice-mayor János Buzáth, to the future location of the memorial plaque, to discuss the details of its installation. This brief piece of news presented the city municipality to be the originator of the initiative and attributed an active role only to the authority regarding decisions on the implementation. One such decision, the choice of the location of the commemorative sign on the building facade, has recently met criticism from the Romani community: at a 2019 workshop on the representation of Roma in urban spaces in Budapest, ${ }^{[19]}$ Romani rights activist Jenö Setét noted that the plaque - due to its out-of-sight position, mounted on a wall above the ground floor - is hardly visible to passersby and, as a consequence, has faded into oblivion by now.

The text on the plaque, which refers to Bihari as "the prominent pioneer of national music," does not mention that he belonged to the Romani community and that his home in the district was located in

18 The first piece of news mentioning the plans to install a memorial plaque for Bihari in Ferencváros, published on 3 April 1927, attributed the initiative to Buday and Pálos (Budapesti Hirlap 1927a). Their related activities were discussed in the article alongside parallel efforts by others to commemorate the composer at a national level, too, led by József Zseny, president of the National Rákóczi Association.

19 "Roma reprezentáció a fóváros közterein" (Romani representation in the public spaces of the capital city), organized by the Tom Lantos Institute at Rácz Gyöngyi Community Center, Budapest, 10 December 2019. 
a neighborhood described in some early twentieth-century accounts as the "Gypsy row" (cigánysor) of nineteenth-century Pest (see Bevilaqua-Borsody 1928), an aspect of the district's history little remembered subsequently. Furthermore, breaking with the standard spelling of his surname, it is engraved on the stone slab in the archaized form "Bihary," in line with Pálos's attempts to obscure the memory of Bihari's Romani background. Pálos, commissioned by a local committee led by Buday (Nemzeti Ujság 1927), made biographical research on Bihari in 1927 and came up with the claim, not supported by any references to primary sources, that Bihari was the grandson of a Hungarian anti-Habsburg rebel, who found refuge in a rural Romani community, which he eventually joined (Pálos 1927, 3). Pálos spelled Bihari’s name with a " $y$ " ending, ${ }^{[20]}$ but this practice was not followed by other biographers of the composer, either before or after him (see Szemere 1824; Mátray [1854] 1984; Major 1928; Sárosi 2002), none of whom made any mention of a putative non-Romani ancestor.

This "de-Romafying" of Bihari's memory at the local level was also manifested in the sidelining of the Romani community at the inauguration event. No representative of MCOE was included among the speakers, and contrary to the plans announced in the press in April 1927, it was the orchestra of the police that performed some of Bihari’s pieces (Tinódi 1928, 250), instead of Romani musicians (cf. Friss Ujság 1927).

A possible intention to suppress the neighborhood's Romani heritage by local non-Roma, an objective surmisable from the above, coincided with the apparent priorities of contemporaneous urban development policy. As some events discussed below indicate, these priorities aimed to concentrate the Romani residents of the city in an outer part of the neighboring eighth district, a neighborhood represented in the press from the 1920s onward as the (new) "Gypsy row" of Budapest (see Malonyai 1921; Pogány 1934; Budapesti Hirlap 1936).

By the late twentieth century it was largely forgotten that the inner part of the ninth district of Budapest was still home to a number of Romani bandleaders - a social elite among Romani musicians (Hajnáczky 2019, 56-58) - in the pre-First World War and interwar periods (see Magyar Czigányzenészek Lapja 1909; BFL IV.1407.b. 21063/925; Krúdy [1930] 1971, 143), ${ }^{[21]}$ that it had a high proportion of Romani residents in the nineteenth century (see S. A. 1903, 10; Bevilaqua-Borsody 1928; Berkes 1943, 14), and that it was also the site of the early efforts of Romani musicians to self-organize, with the first office and community

20 The 1898 handbook of the Central Society for Name Magyarization (Központi Névmagyarosító Társaság) recommended avoiding the use of historical spelling when changing foreign surnames to domestic ones (Telkes 1898, 10) and cautioned that the arbitrary use of such forms, by those bearing names with a modern spelling, had legal consequences (22), while a 1933 decree (40.200/1933. B. M.) explicitly forbade, "for reasons of principle" (2315), to change foreign surnames to "names spelled archaically (e.g. with th, gh, eo, ss), or ending in ' $y$ "' (ibid.). That is, the archaic orthography of Hungarian surnames was a tacit means to express an identity grounded in an ethnic notion of Hungarianness.

21 MCOE, founded in 1908, was originally registered under the address 15 Ráday Street (Magyar Czigányzenészek Lapja 1908c), and so was the club of the association, named Magyar Cigányzenészek Otthona (Home of Hungarian Gypsy Musicians) (Pesti Napló 1908a, Pesti Napló 1908c). Decades before MCOE was founded, a café in nearby Kálvin Square, named Café Ringer, informally functioned as a club and employment agency for Romani musicians and played an important role in the early development of the self-organization of this professional community (Budapesti Hirlap 1897, Pesti Napló 1912). 
space of MCOE set up there in 1908 (Magyar Czigányzenészek Lapja 1908b; Pesti Napló 1908a; Pesti Napló 1908c). Lending official recognition to this local heritage was possibly seen by decision-makers to have a potential to contain Romani residents in the district or even attract MCOE - which moved to the eighth district in the meantime - back, an outcome authorities and dominant society likely wanted to avoid. ${ }^{[22]}$ In contrast, in 1934 the Board of Public Works of the Capital City (Fővárosi Közmunkák Tanácsa, FKT) renamed a street in the outer eighth district - regarded the new "Gypsy row" - after late nineteenth- and early twentieth-century Romani songwriter Pista Dankó (HU BFL II.1.a. Vol. 63 [1934], 523-524), to the protest of non-Romani locals. ${ }^{[23]}$

An interest group led by local landlords claimed in a petition, signed by 387 supporters, that the name choice had caused them damage because "better tenants" were unwilling to live in a street with such a name (F. B. 1935). "We acknowledge that Pista Dankó has merits in composing Hungarian folk songs, but after all he was only a Gypsy [cigány] and thus we hold that it would not be advantageous, either locally or internationally, if the street bore [his] name," reads the petition (ibid.), which also disclosed that its drafters intended to erase the - as they phrased - "Gypsy character" (cigányjelleg) of the street (ibid.). After FKT refused the petition, leaders of the campaign attempted to eradicate the racialized image of the place themselves by expelling Romani tenants from two blocks of flats in 1938, solely based on their ethnicity (Magyarország 1938a). Eventually, FKT yielded to a compromised version of the campaign and shortened the name to Dankó Street, referring to the "unanimous request of the residents of the street" (HU BFL II. 1.a. Vol. 68. [1939], 25).

FKT's initial refusal to rename Dankó Pista Street, as demanded by the petitioners, suggests that the authority had an intention to keep the community of Romani musicians in this remote part of the city, while the opposite seems to have been the purpose in the case of inner Ferencváros, a neighborhood adjacent to the city center, where the acknowledgment of Bihari's Romani background remained a suppressed part of his locally revived memory.

22 The five-floor building on the corner of Kinizsi and Lónyay streets (Figure 3), which bears the memorial plaque (Figure 4), would have been an ideal home for MCOE, as the key activities of the organization included providing a community space for Romani musicians in a café associated with the organization, usually in the block of flats hosting the office. The ground floor of this building on Lónyay Street was designed to function as a café (HU BFL XV.17.d. 329-36961), and it was indeed used as a restaurant at the time of the plaque's inauguration (HU BFL IV.1478.a. 10441/922.). MCOE was in a constant search for a long-term venue for its office since its establishment in 1908, gradually shifting its headquarters from the inner part of the ninth district to the outer part of the eighth district. In 1928 the office of MCOE and the editorial office of its newspaper, both located in the outer eighth district at that time, moved back to the inner ninth district - to an address (16 Kinizsi Street) only a few blocks away from the plaque - for a short period, as contact details in the 1928/6-12 (November-December) issue of the newspaper reveal (see also Ujság 1929a). It is unknown whether this brief return of MCOE's activities to Ferencváros was in a casual relationship with the installation of the plaque.

23 The street, located in the outer part of the district, was previously named after nineteenth-century Hungarian dramatist Imre Madách and the reason for the reconsideration of this decision was the plan to name a new avenue in another district, near the historical center of the city, after Madách (HU BFL II. 1.a., Vol. 63 [1934], 523). The notes of the 6 November 1934 meeting of FKT, announcing the proposal, refers to Dankó as "the renowned Hungarian song and music poet" (524) and does not offer an explanation for the name choice. The street and neighboring Mátyás Square were identified in the popular imagination of the period as home to many Romani musicians (cf. Malonyai 1921; Pogány 1934; Budapesti Hirlap 1936). It is known that Dankó spent his late years in Budapest around the turn of the century, but in the volumes of the Budapest Address and Apartment Index (Budapesti Czim-és Lakásjegyzék) between the year of its first edition (1880) and his death (1903), there are no traces of him among the residents of this street. 
Bihari's belonging to the Romani community was recognized on the pedestal of his bust on Margaret Island, inaugurated a day after the plaque was installed in the ninth district. But this recognition was confined to a small and rather cryptic emblem, ${ }^{[24]}$ invisible on surviving photographs, and this aspect of his identity received marginal attention in the speeches at the inauguration of the sculptural work. The sizable, head-high wooden pedestal, with Transylvanian-style carvings conjuring up associations of irredentism, was by far the most visible extrasculptural element of the structure. In defiance of Bartók's disavowal of the "Hungarian-Gypsy tradition" in art music, some talks at the inauguration on Margaret Island conceptualized Bihari as the first great national composer, who developed a national tradition of authorial music that is rooted in folk music, saving the latter from neglect and oblivion (Tinódi 1928, 251-252). As mentioned above, in the interwar period cultural politics in Hungary embraced this folkrooted tradition in popular music - primarily cultivated by Roma - to offset the impact of international culture in the country, especially seen to manifest itself in the increasingly cosmopolitan character of the capital city. Margaret Island became a symbolic space in public discourse on this issue, after a former MP complained in an opinion piece in early 1928 that no restaurants on the island contracted "Gypsy bands" the previous summer (Magyar Cigányzenészek Lapja 1928; Urmánczy 1928). As the coverage of the inauguration event of Bihari's bust in the weekly Ország-Világ testifies, speakers - representatives of public authorities and civil society - did not spare racist turns to degrade jazz, such as "whining Negro dance music" (Tinódi 1928, 251) or the "inchoate, earsplitting disharmonies of wild peoples" (252), also evoking the trope of the Guilty City (252), then popular among nationalists (Vari 2012, 715).

Bihari's association with the military ethos in early nineteenth-century Hungary was also an important point of reference in the speeches and the visual setting of the event (Tinódi 1928, 251-252), conforming to the strong irredentist spirit of the time. Besides the fact that the verbunkos style, a hallmark of Bihari's oeuvre, was developed from music used for military recruitment in the eighteenth and nineteenth centuries (Sárosi 1971, 80-81), this association in part relied on the composer's own participation in recruitment campaigns for the army of the Hungarian nobility at the time of Habsburg involvement in the Napoleonic Wars, and on his possible yet never-confirmed authorship of the "Rákóczi March," a nineteenth-century patriotic piece of music. For the National Rákóczi Association (Országos Rákóczi Szövetség), one of the original advocates for the bust (Tinódi 1928, 250), ${ }^{[25]}$ it was the context of Hungarian irredentism in which the cult of Rákóczi was reinterpreted (Kovács 2005). Bihari’s figure, as a part of this cult, was likely hoped by the organization to contribute to the revival of a martial ideal, and it was only

24 Bihari's Romani identity was acknowledged in the form of "the coat of arms of the Gypsy people [cigányság], a hedgehog" (Tinódi 1928, 251) etched on the bronze plaque mounted to the pedestal of the bust. An image of this animal was also used as an alleged symbol for Roma on the cover of a biographical encyclopedia of Hungarian Romani musicians, edited by journalist Miklós Markó - one of the initiators of the bust (Tinódi 1928, 252) - published in 1896, and, before that, on the title page of the archduke Joseph Karl of Austria’s Romani grammar book (Czigány nyelvtan: Románo csibákero sziklaribe. Budapest: Hungarian Academy of Sciences, 1888).

25 The president of the association, József Zseny, established a committee to initiate a national-level commemoration of Bihari in the form of a memorial year, the aims of which included the creation of a public statue for the composer (Tinódi 1927, 250). Other known proponents of the bust were journalist Miklós Markó and writer Gyula Pekár, the latter of whom headed the advocacy body (associated with Zseny's committee) campaigning for the sculptural monument (251-252). As in the case of Buday and Pálos in the ninth district, none of these leaders of these initiatives were known to be of Romani background. 
at the price of militarizing the concept of the nation that a Roma, portrayed in hussar uniform and with a musical instrument in hand, received a temporary invitation inside the boundaries of this national community in interwar Hungary.

This tradition of representing Bihari's figure, rooted in János Donát's 1820 oil portrait of the composer, has rarely been paired with discussions about how dominant society exploited Roma in wartime. This exploitation is revealed, among others, by an exchange of letters between authorities regarding an 1814 request by Bihari himself to exempt members of his band from conscription (Isoz 1928, 122-123; see also Sárosi 1971, 73), first discussed by music historian Kálmán Isoz in 1928, in a short text exceptional among writings on Bihari in its sensitivity to racialized power relations. In its resolution on the issue, recommending the refusal of the request, the city council of Pest argued that Roma (zingaros) can be made better use of in wartime than in peace (Isoz 1928, 123), ${ }^{[26]}$ that is, as Isoz concluded, "the [authority] did not consider Gypsy musicians [cigányzenészek] to be fellow citizens of equal rank with other residents" (123). A poem by nineteenth-century Hungarian poet Mihály Tompa also refers to the exploitation of the Romani community for military purposes, which took advantage of the socioeconomic disempowerment of this group (Tompa [1849] 2003, 581), well before better-known manifestations of this practice during the two world wars. ${ }^{[27]}$

Due to a road accident that severely injured his left arm in 1824, Bihari spent the end of his life in poverty in Ferencváros (Mátray [1854] 1984, 295), and he received a rather modest funeral, with low interest from dominant society (Balla 1862). However, in the inauguration speeches of his bust in 1928, he was not contrasted in terms of social rank to the environment of the bronze figure, Margaret Island being an urban recreation area then mostly associated with upper classes (Fövárosi Közlöny 1928, 1771-1773; Magyar 2004, 157-160). This selective rendering of Bihari's biography is suited to the appropriation of his figure by aristocratic nationalism, an identity discourse that made "HungarianGypsy music" a symbol of the culture of the social elite. ${ }^{[28]}$ Bihari's abandonment in old age was not an

26 Acknowledgments are due here to Julianna Orsós and András Kállai for the translation of a sentence from Latin to Hungarian from the city council's letter to the palatine of Hungary, quoted in Isoz's article.

27 Tompa’s poem “Más a császár katonája, más a haza katonája” [The emperor’s soldier and the homeland’s soldier are not alike] addresses a situation in which a draftee is exempted from military service by the arrangement for a paid Romani surrogate to replace him ("The lady hired a Gypsy [cigány] in place of his son for a high price" [Tompa (1849) 2003, 581]), which implies that the paid redemption of the privileged from conscription was a known practice at that time. In the early twentieth century, it was in reference to war needs that the 15.000/1916 circular decree, which ordered the forced settlement of itinerant Roma, also called for the confiscation of their horses and conceding these animals to the army (15.000/1916. B.M. eln., 440). For a survey of the military labor service of Roma during the Second World War, see Bársony ([2004] 2007, 36-37) and Karsai (1991).

28 In Bihari's life, Margaret Island was owned by the palatine of Hungary (the representative of the Habsburg monarch in the country), who maintained a summer residence on this island of the Danube (Magyar 2004, 149-151). In 1815 Bihari gave an openair concert on the island on the occasion of the grand duchess Catherine Pavlovna of Russia's visit to the incumbent palatine, the archduke Joseph Anton Johann of Austria (Mátray [1854] 1984, 293; Major 1928, 18). Although the building of the former palatial residence, in the middle of the island, was still standing in 1928, Vaszary's work of art was installed instead near a restaurant (built in 1869) on the southern part of the island, due to the fact that in this location the sculptural item was exposed to the sounds of live "Gypsy music" when it was performed in the restaurant (Budapesti Hirlap 1928b, but see also Magyar Cigányzenészek Lapja 1928). As it likely happened in the case of the memorial plaque in the ninth district, MCOE was also not represented in the committee that chose the location for the bust on Margaret Island (Budapesti Hirlap 1928b). 
infrequent phenomenon among Romani musicians even over a century after his death, as revealed by a 1937 article in Budapesti Hirlap that reported on the sight of "onetime celebrity bandleader[s], who once made Gypsy people [cigányság] proud” begging in cafés in Budapest from the earnings of their younger colleagues (Budapesti Hirlap 1937c). MCOE already declared a plan to establish a pension fund for its members upon the foundation of the organization in 1908 (Magyar Czigányzenészek Lapja 1908a, 1908c) and, after repeated statements of this intent in the 1920s and 1930s, ${ }^{[29]}$ made attempts to introduce some welfare services for its members in the late 1930s. ${ }^{[30]}$ Despite the fact that MCOE was officially represented at the inauguration of Bihari's bust, even if only in a voiceless role by its nonRomani honorary president, ${ }^{[31]}$ the parallel between the prospects of Romani musicians for old age then and a century before, and the recent self-reliant efforts of the Romani community to advance their situation, remained unspoken at the event.

Members of the Romani community participated in the ceremony only by supplying music: a joint performance of 47 Romani musicians was a program element that received much attention in the press. This placement of Roma outside the intellectual sphere, a frequent manifestation of antigypsyism, was notably challenged only in the speech of Iván Rakovszky, president of FKT. Speaking in the name of the public body that took charge of the bust after its inauguration, Rakovszky compared, at some length, the significance of Bihari's legacy to that of nineteenth-century poet of national epics János Arany, whose stone bust (Alajos Stróbl, 1912) was an iconic sight on the opposite, northern part of the island, and continues to be part of that environment today. ${ }^{[32]}$ This comparison of the two figures projected a future for the two sculptural works with equal importance in the heritage landscape of the capital city's popular outdoor site. However, this pledge could not be met for long, only until the emerging movement of Romani empowerment in Hungary laid claim on Bihari's figure in the ensuing decade and, as a corollary, on the use of the bust as a lieu de mémoire.

\section{An Incomplete History of a Sidelining}

It was apparently inspired by the installation of the composer's bust on Margaret Island that MCOE attempted to make Bihari's figure an icon of the community of Romani musicians in Hungary in the increasingly hostile ideological and political environment of the 1930s. On the domestic front, "HungarianGypsy music" continued to face ideological attacks from ethnomusicology, while in Germany Romani

29 The 1923 statutes of the organization - which existed intermittently between 1908 and 1944 - also include the plan of a pension fund (MCOE 1923, 2, 7-8), while the 1936 statutes mention aims to launch a "home for Gypsy musicians" (cigányzenész otthon) and to provide financial aid to members of the organization in extraordinary cases (MCOSz 1936, 2).

30 For example, in July 1937 the organization started to develop a registry of disabled, unemployed, and elderly Romani musicians and announced plans to open a club for unemployed Roma in the eighth district of Budapest (Budapesti Hirlap 1937d).

31 János Ilovszky laid a wreath on the bust but did not deliver a speech at the event (Tinódi 1928, 252).

32 József Zseny, one of the four speakers of the event, briefly also drew parallels between Bihari and poet Dániel Berzsenyi (Tinódi $1928,251)$, each other's contemporaries, but this one-sentence remark was dwarfed in significance by Rakovszky's more systematic comparison of the composer and Arany. 
musicians from Hungary met political obstacles to practice their profession, as they became open targets of racial harassment and persecution. ${ }^{[33]}$ With all this exacerbated by the increase of antigypsyist measures of authorities in Hungary and the existential crisis of the profession, MCOE made efforts to improve the social acceptance of "Hungarian-Gypsy music" through campaign events that often involved the use of public urban spaces.

After the 1928 inauguration of Bihari's bust on Margaret Island, the composer's figure came to the fore in the organization's public image. This included the launch of a music school by MCOE in 1929, named after Bihari (Ujság 1929b), the adoption of a new logo with a schematic drawing of Vaszary's sculptural piece (HU BFL IV.1409.c. 134.790/1930-IV), as shown in Figure 5, the use of the bust's original plaster version on the stage of a fundraising music event organized by MCOE in 1930 (Figure 6; see also Tolnai Világlapja 1930), the use of an etching of Bihari's portrait on the cover of the organization's 1936 statutes, and an attempt by MCOE to establish a prize named after him (Friss Ujság 1937).

As a further step to reappropriate Bihari's figure, in April 1937 the association organized a public commemoration of the 110th anniversary of the composer's death. This event, as its scant documentation suggests, took place on Margaret Island, at the clearing around the bust, as the launch-event of a fivemonth series of events organized by MCOE - apart from this kickoff ceremony, outside the island - to celebrate the fifth centennial of the presence of "Gypsy music" in Hungary (Városok Lapja 1937). The tentative program of this jubilee year received significant preliminary exposure in the press in March; therefore, the sculptural piece on the island could become connected in public consciousness with a planned Roma-organized event, which - as will be shown below - possibly also had its consequences on the future of the bust.

Another much-publicized event on the island that year was the reopening of a restaurant, located just next to the green area surrounding the bust, ${ }^{[34]}$ in May, after a substantial reconstruction of the building by the establishment's new operator (Budai Napló 1937). It was also around this time that the history of Vaszary's art piece took a new direction, becoming the object of sidelining (in both physical and symbolic senses), well before it was destroyed in the Second World War. As the newspaper Ujság exposed in July 1937, some months earlier FKT relocated the sculptural item from its highly visible position along the main road of the island to a remote place on its eastern shore, largely hiding it from public view (Kenyeres 1937). Upon the newspaper's inquiry, the authority explained the move by claiming that there had been a scarcity of space around the bust, which, according to FKT, became evident during that year's Bihari commemoration in April (the authority attributed the National Rákóczi Association to be the organizer

33 In 1930 a group of 30 Nazi sympathizers in uniforms protested in Café Luitpold, Münich, against the performance of Romani musicians from Hungary at the venue, calling for their banishment on the pretext of unemployment in the country (Budapesti Hirlap 1930), while in 1936 a Romani youth orchestra from Hungary was expelled from Nazi Germany by state authorities on grounds of its members not being Aryan (Gál 1936).

34 The presumably original position of the bust is highlighted on tourist maps of Budapest published around 1930 (Klösz György és Fia 1930?, Lloyd Könyvek Kiadóvállalat 1930?), revealing that Vaszary's work was placed on a patch of land to the west of the restaurant on the southern or "lower" part of the island, popularly known then as "lower restaurant" (alsó vendégló) or, from the late 1930s, as Casino. 
of the event). FKT also referred to plans for a "Gypsy congress" (cigánykongresszus) to be held later that year in Budapest, which was discussed earlier in the press as a future event of MCOE (Budapesti Hirlap 1937c; Pesti Hirlap 1937a; Pesti Napló 1937a, 1937c). The authority presumed that the participants of this scholarly event would visit the bust on the island and contended that its former location, by the restaurant, "would be even less sufficiently spacious for such a purpose" (Kenyeres 1937) than it was for the April commemoration.

The 1936 and 1937 meeting notes of FKT (HU BFL II. 1.a. Vols. 65-66) contain no reference to the relocation of the bust, as neither does any other official record or publication of the authority consulted as part of this research, including the registries and general administrative documents of Margaret Island for those years or a monograph by FKT-member Ferenc Harrer summarizing the activities of the authority between 1930 and 1940, with a chapter devoted to development activities on the island. ${ }^{[35]}$ Since there seems to be no official documentation of the relocation, a range of possible explanations can be considered for the move. An attempt to outline one such hypothetical scenario follows in the remainder of this section and in the next one, inspired in part by the concept of the "duality of heritage" (Graham, Ashworth, and Tunbridge 2000, 22), which reckons with the simultaneous embeddedness of heritage in the cultural and economic realms.

The investigative article in Ujság seemed to be satisfied with the reply of FKT, though the argument of the authority would sound plausible only if the green area around the bust - "a clearing surrounded by weeping willows" (Tinódi 1928, 251) - were known to have been reduced in size since the installation of the art piece in late 1928. Up to the submission of this paper, no site plan of the original surroundings of the bust was found. The first maps showing Vaszary's work known to the author of this article date from around 1930 (Klösz György és Fia 1930?; Lloyd Könyvek Kiadóvállalat 1930?) and they locate it on a green patch of land, a sizable traffic island between the main road and the restaurant, an area that survived in an unchanged form up to 2018. A 1926 site plan (HU BFL XV.17.d.322.a./57.b.) still showed a larger green area in that location, with a different shape. But a major reconstruction of the main road of the island (Budapesti Hirlap 1928a), the plans of which involved transformations of that land piece (HU BFL XV.17.d.322a./57.c.), was started in early 1928, that is, approximately half a year before the bust was installed. ${ }^{[36]}$ Therefore, it can be assumed that by late 1928 the green area had taken the size and the shape that are seen on later maps, and that Bihari's two commemorations on the island, in 1928 and 1937, thus happened in identical environments.

35 In relation to the displacement of Bihari's bust on Margaret Island in 1937, this research included studying resources in the following sections of the Budapest Capital City Archives (Budapest Főváros Levéltára, BFL): the Records of the Board of Public Works of the Capital City (HU BFL II.1.), the Central Archive of the Mayor's Departments of the Royal Seat and Capital City of Budapest (HU BFL IV.1409.c.), the Records of the Magistrate's Office of the Third District of the Royal Seat and Capital City of Budapest (HU BFL IV.1472.a.), and the Plan Collection of the Royal Seat and Capital City of Budapest (HU BFL XV.17.d.).

36 Between 1930 and 1940 Harrer mentions only one intervention that could have possibly affected the landscape around the monument - in 1937 a second driveway was built between the main road and the restaurant $(1941,208)$ - but a map (BFL 1937) and an aerial photograph (Fortepan/MKHL 1944) suggests that this transformation procedure did not involve any changes to the green area that supposedly hosted the bronze bust of Bihari. 
In the ample press coverage of the 1928 inauguration ceremony, there were still no complaints about a lack of space around the bust, though, as seen before, that event included a large-scale music performance, with an orchestra-size casual ensemble of Romani musicians. In a contradictory manner, FKT, in motivating the relocation of the bust in 1937, referred to a scarcity of space in the context of a presumably smallerscale commemorative event at the same venue that year (i.e., 1937). ${ }^{[37]}$ The article in Ujság - apparently the only press discussion of the relocation - did not mention whether the new site of the sculptural work, a shore protrusion along a walkway on the eastern shoreline, was better suited for public events than the original. However, the author of that article complained that he found the spot only with some difficulty, it being outside the main routes of pedestrian traffic (Kenyeres 1937).

This physical sidelining of the bust was soon followed by its partial erasure from the public image of Margaret Island. In a richly illustrated 1940 monograph on the island, written by archivist Dezső Rexa (who personally represented Pest County in the 1928 inauguration of Vaszary's work of art [Tinódi 1928, 252]), Bihari's bust is the only sculptural item on the island that is not photographed, even if its presence is briefly acknowledged in the text (Rexa 1940, 36-37, 38). Rexa's notable disregard for Vaszary's artwork is in stark contrast with deputy mayor Endre Liber's earlier, 1934 book on the public statues and monuments of Budapest, in which, out of the five discussed sculptural objects on the island, more space is devoted to the composer's bronze figure (346-349) than to the remaining four art pieces together $(299-300,370-372){ }^{[38]}$ The large volume of Liber's treatment of Bihari's bust is largely due to his detailed summary of the grand inauguration ceremony, ${ }^{[39]}$ the magnitude of which remained unmatched on the island until $1940^{[40]}$ and which invested Bihari's bust with the function of a memory site from the beginning.

37 The music program of the 1937 Bihari anniversary on Margaret Island included open-air concerts by Imre Magyari's "Gypsy band" and the Turkish pipe band (tárogatózenekar) of the National Rákóczi Association (Pesti Hirlap 1937b). No detailed press reportage on this commemoration has been found during this research, only a brief, two-sentence news piece, which - though published two days after the event - seems only to summarize the content of the preliminary press announcements of the event's program, in a rather telegraphic manner (Kis Ujság 1937b). A notable tendency in these brief news pieces is that, while those published in mid-March still attributed MCOE to be the organizer of the event (Pesti Hirlap 1937a; Pesti Napló 1937b), those published in late April, just before the event (Kis Ujság 1937a; Pesti Hirlap 1937b; Pesti Napló 1937d) or - in the abovementioned single case - after it (Kis Ujság 1937b), replaced the name of the organization with that of the National Rákóczi Association and spelled Bihari's name in the historicizing form "Bihary." FKT also attributed the commemorative event to this (not Roma-focused) association instead of MCOE in its response given to Ujság in May 1937 regarding the relocation of Bihari’s bust (Kenyeres 1937). As compared to the amount of press interest on some later events of the five-month program series by MCOE in 1937, none of which took place on Margaret Island, the lack of in-depth coverage on the 1937 Bihari anniversary is remarkable, just as the absence of MCOE's name from some of the news items related to this commemoration of the composer.

38 Liber, who represented the mayor's office of the capital city at the inaugurations of both the plaque and the bust dedicated to Bihari in 1928 (Tinódi 1928, 251), had already passed away by the time when the bust was relocated in 1937. Similarly, a number of those who were actively involved in its creation or installation were already not alive, like Miklós Markó and József Zseny, or did not hold their former position, such as Iván Rakovszky.

39 The inauguration ceremony in 1928 was not only large-scale but also well-documented and highly-publicized, with examples such as a nearly three-page reportage in the broadsheet weekly newspaper Ország-Világ, which included the transcripts of all the speeches (see Tinódi 1928, 250-252), or a cinematic newsreel by the state-sponsored Magyar Film Iroda Rt. (1928). The latter piece of information is owed by the author of this article to Zoltán Vaszary.

40 Up to the mid-twentieth century, only Mihály Tompa’s stone bust on Margaret Island (János Pásztor, 1940) had an inauguration ceremony that was comparable in terms of scale and publicity to Bihari’s (Magyar Országos Tudósító 1940). 
If looking for possible reasons for the eventual marginalization of this bronze figure in the physical and symbolic realms of the island, one can only rely on considering a range of contextual factors. One possible area of inquiry is the increased visibility of Roma in urban spaces across Central and Eastern Europe in the interwar period, which was partly the result of the emergence of Romani empowerment movements in the region at the time, as some examples highlight below. In Hungary, this development coincided with the fact that Budapest became a target of mass international tourism from the 1920s (Sipos 2005, 157; Vari 2012, 278), which not only opened new economic opportunities for Romani musicians but also posed new limits to their freedom.

\section{Places of Consumption and Racialized Urban Spaces}

The founding meeting of MCOE in a café in the inner part of the seventh district of Budapest in 1908, attended by about 150 Romani musicians (Pesti Hirlap 1908, Pesti Napló 1908b), foreshadowed activities by the organization that involved new uses of public urban spaces by this professional group, including general assemblies, strikes, and campaign events, which never failed to raise press interest and gain wider public visibility. ${ }^{[41]}$ From the 1930s, the press in Hungary also regularly covered events related to Romani self-organization in other countries, such as a congress in 1933 in Bucharest, Romania, reportedly with 10,000 participants (Népszava 1933). ${ }^{[42]}$ Of these events, the Romani pilgrimage to Saintes-Maries-de-la-Mer, France, has a special relevance to the phenomenon addressed in this section, as at the center of this tradition is the cult of a statue in the Romani community, which periodically involves the communal use of public urban spaces in connection with an art object. ${ }^{[43]}$ In 1934 the daily Magyarság published a series of photographs of the annual event in southern France, commenting in the caption that "the otherwise quiet settlement turns into an endless nomad camp within hours” (Magyarság 1934, 8).

As it was already shown through an example, the mere use of public spaces by Romani musicians for purposes other than providing entertainment was at times claimed in administrative and public discourse in Hungary to conflict with the purported interests of the tourism industry, with fears being voiced that the sight of Roma in central Budapest, without playing music, would deter tourists. A similar concern was raised in an article in an April 1937 issue of the daily Az Est, discussing the recent urban development

41 Additionally, the presence of large numbers of unemployed Romani musicians gathering in public spaces of Budapest in the 1930s, such as Grand Boulevard (Nagykörút) (8 Órai Ujság 1934) and Mátyás Square (Budapesti Hirlap 1936) was also highlighted in some pieces of reportage on the existential crisis of the profession, a commonly discussed topic in relation to Romani musicians in the press of the period.

42 The September 16, 1934 issue of the daily newspaper Népszava illustrated a news piece on a similar "Gypsy congress" (cigánykongresszus) in Romania with a photograph showing audience members of the event (10).

43 Saintes-Maries-de-la-Mer on the southern coast of France is a place of pilgrimage for many Roma, from inside and outside the country, due to the supposed historical connection of this locality with the person of Sara e Kali (Sara the Black), the unofficial patron saint of Roma. At the center of this pilgrimage, first recorded in the mid-nineteenth century, is a wooden statue of Sara in a basement shrine of a church, an art object which, since 1935, is carried to the sea amid a procession of veneration annually on 24 May (Wiley 2005, 135-136). 
activities of FKT to boost international tourism in Budapest. After a lengthy praise of these efforts, citing Margaret Island among the examples, the article - published weeks before the Bihari commemoration on the island, planned by MCOE, was due - concludes, with a sudden change of topic, by targeting Roma: "And let there be rest in this country and peace. The Gypsy [cigány] should make noise only when they are playing czardas...” (Az Est 1937).

Against such a background, it might be asked whether the new operator of the restaurant on the lower part of Margaret Island, renamed as Casino Caffe-Restaurant after the 1937 refurbishing, could assume that the recent interest in the bronze figure by MCOE could make this location on the island associated in the public imagination with Romani presence, an image possibly already projected on that place by advance press discussions of MCOE's locally planned event. If the leaders of the company running the restaurant, Palatinus Park Rt., had such concerns, they might also have perceived this space of possible power inversions, a special zone in the "purified environment" (Sibley 1995, 78) of the island, to pose a risk for nearby "spaces of consumption" (xii). As discussed above, in 1934 it was also on the pretext of an alleged economic necessity that property owners in the eighth district of Budapest (unrelated to Margaret Island) launched a campaign against the recent decision by FKT to name a street in the outer part of that district after Pista Dankó, a Romani songwriter, followed by their (local landlords') attempts to purge the street of its "Gypsy character," both in a symbolic and social sense.

If the management of Palatinus Park Rt. was afraid that the Bihari bust, as a place of possible future memory practices by the Romani community - that is, a place of regular Romani presence - could also give such a "Gypsy character" to the patch of land right next to the restaurant on Margaret Island, it apparently had some means to take action against it. The company held much power over the island, having long-term concessions to run most of its business establishments, and was also a major investor in its infrastructural development (8 Órai Ujság 1933), while its founder, Mihály Gellér, was appointed senior government counselor in 1936 (Magyar Közgazdaság 1936). Furthermore, Miklós Horthy Jr., the son of the governor of Hungary, was also a member of the board of directors of Palatinus Park Rt. (Kallós 1937, 536).

Without suggesting to cast other explanations for the sidelining of Bihari's bust aside, ${ }^{[44]}$ this article proposes the possibility that the news coverage of MCOE's planned event near this art object made the place in the perception of the public similar to what Giovanni Picker calls “Gypsy urban areas" $(2017,2)$, and that the removal of Vaszary's work of art by FKT might have served to prevent a periodic presence of the Romani

44 Another possible motivation for the removal of the bust is hinted in the minutes of the 13 April 1937 meeting of FKT. The event was opened with an off-agenda announcement by FKT president Zénó Bessenyey, in which he informed the participants that a spa fountain to be inaugurated on the southern part of the island would be named after the governor of Hungary Miklós Horthy's wife (HU BFL II. 1.a. Vol. 66 [1937], 225). The spa fountain with a nearby drinking pavilion was opened in July 1937 (Ujság $1937 b)$, the latter on the eastern side of the restaurant Casino (Harrer 1941, 210), adding the place to the locations of the personality cult of Horthy (already present on the upper part island [Harrer 1941, 197]), whose cult also exerted an enormous impact on the cultural geography of interwar Budapest. A potential heritage conflict to emerge from the situation is reminiscent of a case in Szeged, a city in southeast Hungary, where in 1912 authorities objected against placing Romani songwriter Pista Dankós statue in the park of Stefánia Promenade, near the statue of the empress consort Elisabeth of Austria, in fear of offending the Habsburg royal family (Móra [1922] 1964, 188). 
community to develop near the adjacent restaurant. In its already quoted argument to Ujság, giving an explanation for the relocation of the bust, FKT anticipated that the art object would draw visits to the island by participants of an international "Gypsyology" congress to be hosted in Budapest by MCOE in September 1937, although the preliminary details of its program in the press (Magyarság 1936a) did not indicate that it would include any events on Margaret Island. Eventually, the congress (an out-of-house meeting of the Liverpool-based Gypsy Lore Society) was canceled weeks before it was due, on the decision of Gypsy Lore Society, citing "obstructions" faced by some of the presenters as the reason (Budapesti Hirlap 1937a). ${ }^{[45]}$

\section{Distancing from the Center}

The (partly hypothesized) story of Bihari's bust showed how a strategy of "marginalizing within centrality" might have been used by authorities in interwar Budapest to prevent the public statue of a Romani musician from becoming a site of memory practices by the Romani community in a central zone of the city, rooted in the capacity of lieux de mémoire "for metamorphosis, an endless recycling of their meaning and an unpredictable proliferation of their ramifications" (Nora 1989, 19). Late nineteenth-/early twentieth-century Romani bandleader Béla Radics's statue in Kerepesi Road Cemetery, Budapest, which is at the focus of the present section, sheds light on how only an off-center and functionally also irregular, heterotopic urban area provided the Romani community with an opportunity for active social participation in a public space in the same period.

Bihari's bust on Margaret Island was destroyed in the Second World War (Berza 1982, 840), just like his fullbody plaster statue (Antal Szécsi, 1889) in Vigadó Concert Hall, Budapest (Nagy 2004, 353). Of the public statues of Romani musicians erected in Hungary before the war, it was only those of Pista Dankó in Szeged and Béla Radics in Budapest that survived the events of 1944-45. Radics's full-body, near life-size bronze statue on his tomb in Kerepesi Road Cemetery, a memorial park-type cemetery outside the central zone of the city, ${ }^{[46]}$ was created as a result of a fundraising campaign by MCOE in 1930 (Magyar Országos Tudósító 1930b). Such campaigns by then had a tradition within the community of Romani musicians in Hungary, an early example of which is a series of fundraising concerts organized by this community between 1885 and 1890 for the benefit of a tomb monument to bandleader Pali Rácz (Vasárnapi Ujság 1885; Fövárosi Lapok 1889; Budapesti Hirlap 1890a), which was inaugurated in 1890 in the same cemetery (Budapesti Hirlap 1890b). Radics's memorial brought a new turn in this representational tradition by incorporating a freestanding statue of the commemorated individual.

Unlike the 1930 fundraising concert of MCOE, a mega-sized open-air music event in a football stadium, the inauguration of Radics's bronze statue two years later was left mostly unnoticed by the press and

45 News reports claimed the event was only to be postponed for a year (Budapesti Hirlap 1937a), and the congress indeed took place in 1938, but in Liverpool instead of Budapest (Magyarország 1938b).

46 Kerepesi Road Cemetery was opened just outside the city of Pest in 1849 (Tóth 1999, 6), along the outer border of the district of Józsefváros (today also known as the eighth district of Budapest). It was classified as an honorary cemetery in 1885 by the general assembly of the capital city (28), and in 1956 it was granted the status of a national pantheon (93). 
the media, apart from a few brief mentions (e.g., Pesti Hirlap 1932). Standing on a stone pedestal in a cemetery block that lies along the main road of the cemetery, Lörinc Siklódy's work of art shows the musician in a dignified standing pose, with his violin under his arm, looking into the distance. ${ }^{[47]}$ Its three-piece suit, with a cutaway coat, has no nationalist associations, unlike many tomb monuments erected in the cemetery in the period, ${ }^{[48]}$ making it also an exception in Siklódy's oeuvre. Lacking any references to the cult of Rákóczi, it is a counterpoint to Bihari' bronze bust on Margaret Island, inviting comparison instead with Dankós pensive figure in Szeged.

Dankós and Radics's statues offer Roma entry to the conceptual space of the nation under different conditions than Bihari's 1889 and 1928 sculptural figures did. Despite its survival of the war's events, Siklódy's work of art has apparently not become an object of memory practices, but it has neither been relegated to complete oblivion. The cemetery block that includes Radics's grave grew to be an area within the cemetery that is partly identified as a final resting place for Romani bandleaders (Tóth 1999, 116; Csapó 2018). ${ }^{[49]}$ Up to the 1940s, the funerals of the Romani musicians buried in this block were spectacular mass events, with grand music performances, attended by thousands and highly publicized in the press. As a 1934 press photograph of Romani bandleader Károly Bura's funeral testifies (Pesti Napló 1934), with a caption also reflecting on the presence of Radics's statue in the background, the bronze figure came to be an emblematic part of this venue, which became a site for displaying and negotiating Romani identities in the interwar period.

In addition to the fact that erecting tomb monuments were privately funded efforts, the peripheral location of the cemetery perhaps also allowed more freedom in self-representation practices through such sculptural commissions. Similarly, probably because of the off-center status of the location, funeral ceremonies in this venue seemingly offered more opportunities for the inclusion of the voices of Roma than did public events in the city center. In the interwar press sources consulted as part of this research, the only mention of a Romani musician giving a speech at a public event was the funeral of bandleader Gábor Kozák in 1926 in Kerepesi Road Cemetery, in which his colleague Béla Radics said farewell to Kozák at his grave, before performing music in his honor (Ujság 1926).

47 The presence of an audience is also implied by the statue (Sturcz 1983, 190), but the performer's status here is not subordinate to it as in the case of Szécsi's Bihari statue in Vigadó Concert Hall. In Sturcz's description, Siklódy's Radics appears "after the performance of a song, receiving applause from the audience, in the moment of success" (ibid.).

48 According to Vilmos Tóth, "extreme forms of militarism, which would have seemed grotesque under other circumstances, gained a foothold" $(1999,77)$ in the heritage environment of the cemetery in the interwar period, manifesting themselves even in epitaphs of private graves. A manifestation of similar tendencies at the level of local politics is that the road along the front wall of the cemetery was renamed Fiume Road in 1923 (Fövárosi Közlöny 1923, 1350; Tóth 1999, 77) in an irredentist spirit after the Hungarian-preferred (Italian) name of the Croatian town of Rijeka, which was under Hungarian jurisdiction within the former Kingdom of Hungary. The largest memorials installed in the cemetery around the examined period included a First World War memorial in 1918 (Tóth 1999, 77) and an equestrian statue on the tomb of the radical right-wing prime minister Gyula Gömbös (1941), "representing an ancient Hungarian leader on horseback" (83).

49 Presently, block 11 of Kerepesi Road Cemetery includes the graves of Romani bandleaders Lajos Boros (Boross) (1925-2014), Károly Bura (1881-1934), Antal Kóczé Sr. (1872-1926), Antal Kóczé Jr. (1895-1959), Lajos Kóczé (1900-1925), Imre Magyari Jr. (1894-1940), Béla Radics (1867-1930), and Kálmán Vörös (1931-2008), besides those of many prominent non-Romani persons. 
But while in mere spatial terms Radics's statue was on the margins of the city, hidden behind the high brick walls of the cemetery, these walls hosted a space with functional features that relate it to the center, as a space of national self-representation. However, unlike major nineteenth-century garden cemeteries in Europe such as Père Lachaise in Paris or the Glasgow Necropolis, Kerepesi Road Cemetery remains a largely invisible part of the city, "almost fully missing from public consciousness" (Tóth 1999, 5). This marginal character of the site might partly explain why the relatively prominent location of Radics's statue in the (often-transformed) topography of the cemetery has not been challenged in the same way as the presence of Bihari's bust along the main road of Margaret Island has been. ${ }^{[50]}$

As city authorities shifted the spatial focus of their memory politics regarding Roma away from the center from 1929, when a street was named after eighteenth-century female Romani bandleader Panna Cinka in what is today the 14th district of Budapest (HU BFL II. 1.a. Vol. 60 [1929-1930], 418-419), MCOE turned its attention back to central areas of the city in the 1930s. The last highly visible activity of the organization was a commemoration day of the fifth centennial of "Gypsy music" in Hungary in May 1937, with open-air concerts simultaneously held in city centers all over the country. If the choice of its site in Budapest, the irredentist monument in Liberty Square (Szabadság tér) ${ }^{[51]}$ was a statement by MCOE of its willingness to cooperate with the ultranationalist regime, the international "Gypsyology" congress planned by the organization for the autumn of the same year expressed its concern over the domestic influence of Nazi ideologies of race. A preliminary announcement of the scholarly event in the daily Pesti Napló summarized that the primary aims of the congress were clarifying the origins of Roma, making a case for the Aryan progeny of this community, and advocating the idea that, as secretary general Béla Mázor put it, "the Gypsy issue [cigányügy] cannot be only a question of public order and public health” (Pesti Napló 1937a).

However, such open forms of political criticism remained exceptions in the history of the organization, which hoped that the Horthy regime would continue to perceive Romani musicians as proponents of Hungary's national music heritage and partners in the past independence struggles of the nation. Arguably, the public events of MCOE served to keep these topics on the agenda of the nationalist discourse in interwar Hungary. Yet the expansion of measures targeting Roma in Hungary in the period was indicative of how readily the state apparatus would soon cooperate with Nazi Germany in the racial persecution and extermination of Roma. In a few years' time, history was to prove that "[w]hen violence erupts, the historical signs of hybridity," in our case, memory sites of Romani musicians, "offer little resistance" (Papastergiadis 2005, 62).

50 In Kerepesi Road Cemetery, the main road gained a new prominence in the interwar period (Tóth 1999, 62), especially due to the 1936 burial of Gömbös near its end and the inauguration of the abovementioned equestrian statue on his tomb five years later, to be removed after 1945 (83-85).

51 The performance of the Romani musicians was incorporated in a changing of the guard ceremony by a radical right-wing organization at the monument (Budapesti Hirlap 1937b). Besides the character of Liberty Square being defined at that time by this 20-meter tall object, called the Reliquary Flagpole of the Land (Ereklyés Országzászlótartó), the square also came to be a site for a number of additional similarly themed statues in the period (Vari 2012, 722-723). 


\section{Conclusion}

As nineteenth-century nationalism, grounded in the political concept of the nation in Hungary, gave way to ethnic nationalism after the First Word War, the figure of the Romani musician remained an exception from a wholesale othering of Roma by dominant society only in limited cases. In such cases, remnants of the nationalism of the previous century were reconfigured to match the new and sometimes conflicting priorities of the interwar period. In relation to Romani musicians, this earlier form of national thought allowed room for the pre-twentieth-century development of a hierarchical and oppressive version of what Ashworth et al. call the core+ model of plural societies, in which a core culture is supplemented by "minority add-ons" (Ashworth, Graham and Tunbridge 2007, 79).

Building on the distinction Ashworth et al. made between inclusive and exclusive versions of the core+ model in long-established societies (144-152), this article proposes to further differentiate in this context between hegemonic and non-hegemonic forms of inclusion. In the former, hegemonic form, dominant society incorporates the heritages of minority groups on its own terms, denying equal participation from the other in the process. In Hungary, the "Hungarian-Gypsy style" in music and the figure of the Romani musician entered the national imaginary under such unequal terms, failing to disrupt power relations. Thus, while Shay Loya - examining the "Hungarian-Gypsy tradition" in an earlier historical setting - holds that "one should not underestimate the power of transculturation to subvert cultural-political structures in nineteenth-century Central Europe" $(2011,13)$, this article instead assumed an analogy between the uses of "Hungarian-Gypsy music" by dominant society in nineteenth- and twentieth-century Hungary and appropriations of the Latin American discourse of mestizaje/mestiçagem for oppressive political practices in these periods (see Martínez-Echazábal 1998, 37-38).

The above analysis attempted to support this argument by a discussion of urban memory sites related to Romani musicians, created in the interwar period, by primarily addressing the history of their social and political uses and their relation to transformations of the social and cultural geography of Budapest at the time. A noticeable formal feature of the two public statues examined - similarly to earlier sculptural representations of Romani musicians in Hungary - is a violin in their hands, which marks the precondition of their presence in the spaces of dominant society, exposing their subordinate role in these spaces. The inauguration ceremonies of János Bihari's bust and memorial plaque near the historical center of the city offered Roma only voiceless forms of participation, while the possibility for this community to have more active involvement in shaping the discourses on and representations of Roma opened up only behind the walls of a cemetery in an outer district.

Attempts by the community of Romani musicians to include Bihari's bust in its memory practices is a possible reason for the secretive relocation of this art piece by authorities to the spatial margins of Margaret Island. In this hypothesized scenario, the statue was seen by dominant society not merely as an object with a signifying value but also one with a potential to draw events organized and attended by Roma to its location on the island. To use Picker's terms for mechanisms of segregating Roma in Europe, the memory communities the bust implied became subject to displacement, which involves relocating Romani communities from city centers, often to remote and underdeveloped areas. In this 
case, a foreseen Romani presence was first banished to the margins of a central urban area (Margaret Island), before the sculptural object was, to a large degree, also expelled from the island's public image. By contrast, Béla Radics's bronze statue was endowed with a relatively central location in a marginal urban zone (Kerepesi Road Cemetery), and its position near the main road of the cemetery was not challenged during the Horthy regime or thereafter. Similarly to the decisions of FKT to name two streets outside the city center after Romani musicians between the late 1920s and the mid-1930s, this political endorsement of Radics's "centrality within marginality" can be related to what Picker calls the strategy of containment, which aims to keep racialized communities on urban peripheries (84-106).

Picker emphasized mainly in the context of displacement that this segregating mechanism - though the same can be argued for other forms of spatial peripheralization that he discusses - "may occur at a symbolic level, too" (48), inferring the "(re)location beyond the ethno-moral boundaries of the nation" (ibid.). As seen above, in interwar Hungary these exclusionary practices, driven by the ideological developments of the period, coincided with the fact that Romani communities in Hungary and abroad started to engage in self-organization, which yielded new types of public visibility for these communities and claims by them for active roles in using, interpreting and shaping urban heritage environments.

\section{Acknowledgments}

This article is partly based on research carried out by its author as a Roma in European Societies (RES) Junior Visiting Researcher at the Romani Studies Program at Central European University, Budapest in 2018. The author is much indebted to the faculty and staff of the program for their support of this work, and to all those who contributed to the development of this text in association with the activities of the program, especially participants of the Art and Representation panel of the conference Critical Approaches to Romani Studies (CEU, Budapest, May 24-25, 2018), in which its preliminary version was presented, as well as to editors and peer reviewers of the journal Critical Romani Studies. Acknowledgments are also due to János Bársony, Ildikó Nagy, the Budapest Capital City Archives, CEU Library, the Collection of Local History of Ferencváros (Budapest), Fejér County Archives of the National Archives of Hungary (Székesfehérvár), Gemer-Malohont Museum (Rimavská Sobota, Slovakia) and the Ráday Archives of the Danubian Reformed Church District (Budapest). Unless otherwise noted, all translations are by the author. 


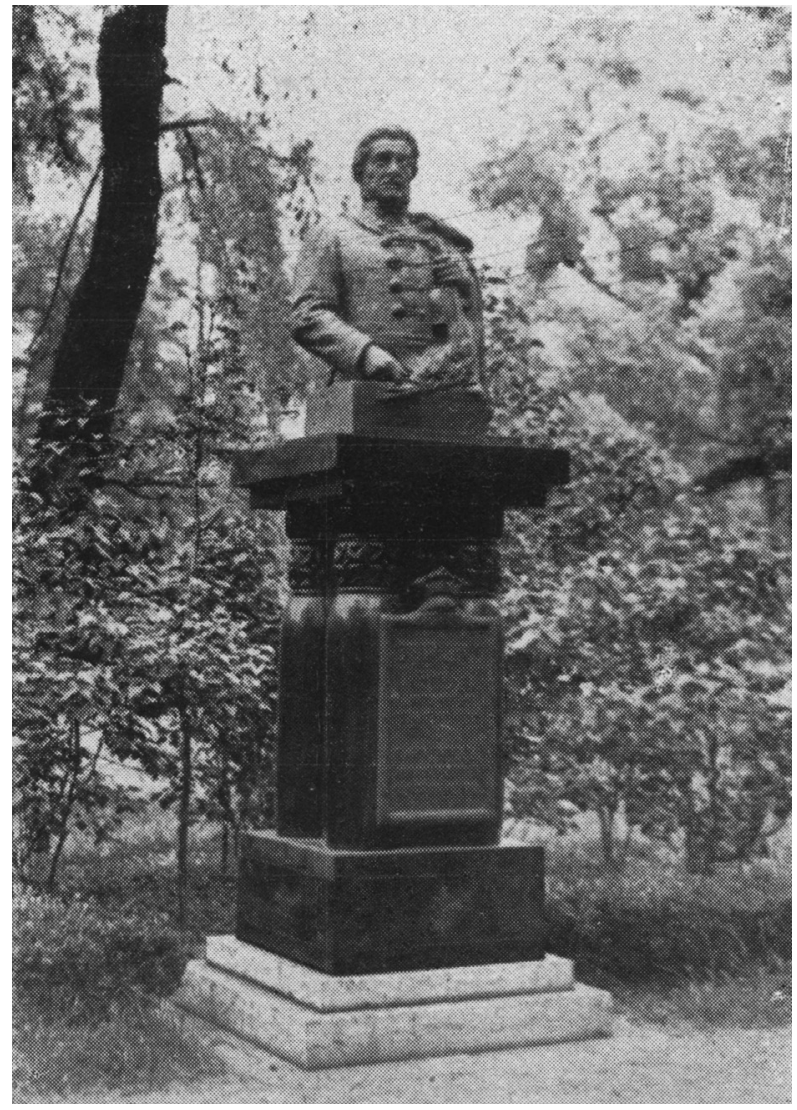

Figure 1. László Vaszary. János Bihari. 1928. Bronze. Margaret Island, Budapest (1928-1944/45). In Budapest szobrai és emléktáblái (The sculptures and memorial plaques of Budapest) by Endre Liber (Budapest: Budapest Székesfóváros Statisztikai Kiadóhivatala, 1934), 347. Reproduced with the permission of the Metropolitan Ervin Szabó Library, Budapest Collection.

Figure 3. Memorial plaque to János Bihari. 34 Lónyay Street, Budapest, 1928. Photo by the author.

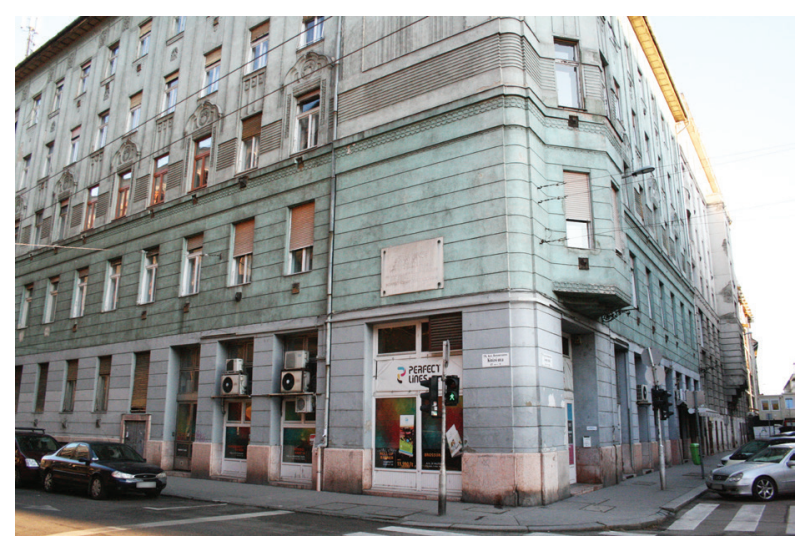

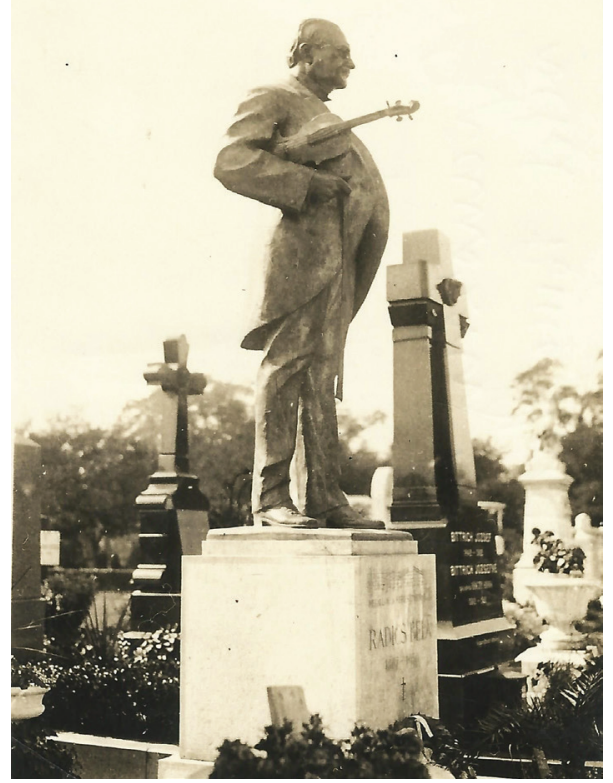

Figure 2. Lőrinc Siklódy. Béla Radics. 1932. Bronze. Kerepesi Road Cemetery, Budapest. Reproduced with the permission of the Hungarian Museum of Trade and Tourism.

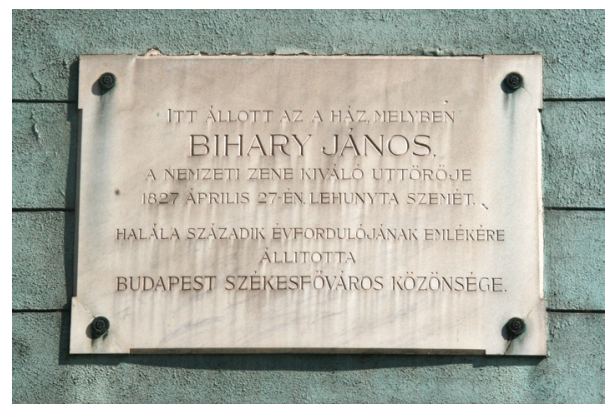

Figure 4. Memorial plaque to János Bihari. 34 Lónyay Street, Budapest, 1928. Photo by the author. Text of inscription: "Here stood the house in which János Bihary, the outstanding pioneer of national music, closed his eyes on 27 April 1827. In memory of the centenary of his death installed by the public of the Royal Seat and Capital City of Budapest." 
MAGYAR CIGÁNYZENẺSZEK ORSZÁGOS EGYESÜLETE TEL. 1. 398-62. BUDAPEST, VIII,, JOZZSEE-KÖUUT 16. É NËMET-U. 13.

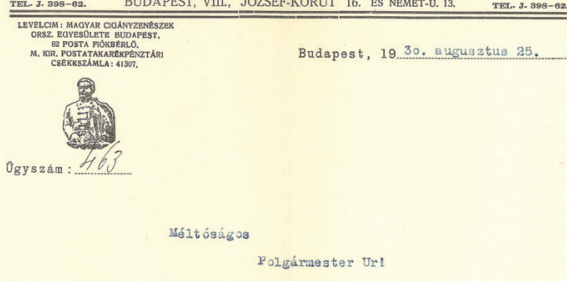

Tigztelettel bejelentj lik, hagy hivatel oo lapunic

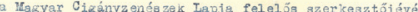

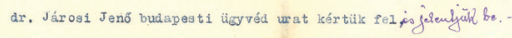

Ugyvédi Kamarai kivanatát

Igraben bejelentjikr, hogy a lapunkat készit oñ nyourla

citre Haulovits Imre,VII.Veaselény1-u 3o.

Piaz telettel kérjuk bejelentésinic trdonásulvátelét.

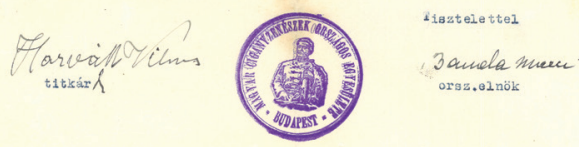

Figure 6. A fundraising concert for Béla Radics's tomb monument, organized by the National Association of Hungarian Gypsy Musicians in a football stadium on Üllői Road, Budapest, on 29 May 1930. Still from newsreel footage (Magyar Hiradó [Hungarian News], episode 328, June 1930, Budapest: Magyar Filmiroda Rt.). Reproduced with the permission of the National Film Institute Hungary - Film Archive.
Figure 5. Letter from Marci Banda, the president of the National Association of Hungarian Gypsy Musicians, to the mayor of Budapest, 25 August 1930. Reproduced with the permission of the Budapest City Archives.

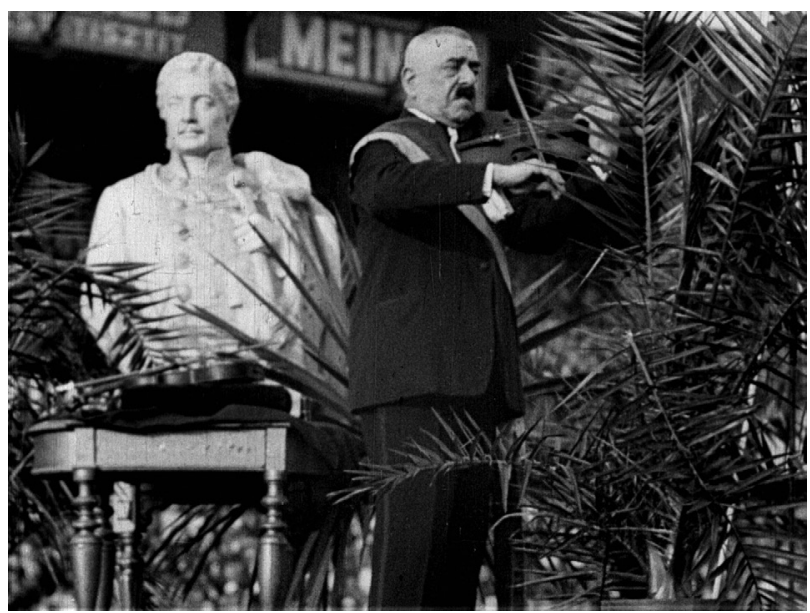




\section{References}

8 Órai Ujság. 1933. "25 évre bérbe adták a Margitszigetet” [Margaret Island leased for 25 years]. 21 October 1933, 1.

—. 1934. "Budapesti cigánysoron nagy a sírás-rívás... 'Hiénák' kezébe került a cigányság - Nagy akció a háromezer népzenész megmentésére" [Loud is the wail on the Gypsy row of Budapest... The Gypsy people in the hands of 'hyenas' - Big campaign to save 3,000 folk musicians]. 2 December 1934, 5.

15.000/1916. B.M. eln. “A m. kir. belügyminiszter 1916. évi 15.000. eln. számú rendelete, a kóbor (sátoros) cigányokról” [The Hungarian royal minister of the interior's decree of the year 1916, numbered 15,000, on wandering (tent-dwelling) Gypsies]. Magyarországi Rendeletek Tára: Ötvenedik folyam: 1916. Budapest: Magyar Királyi Belügyminisztérium, 1916, 438-447.

https://library.hungaricana.hu/en/view/OGYK_RT_1916/?pg=443\&layout=s

40.200/1933. B. M. “A m. kir. belügyminiszter 1933. évi 40.200. számú rendelete, a névváltoztatás szabályozásáról”

[The Hungarian royal minister of the interior's decree of the year 1933, numbered 40,200, on regulating name changes]. Magyarországi Rendeletek Tára: Hatvanhetedik évfolyam, 1933. Budapest: Magyar Kir. Belügyminisztérium, 1933, 2313-2316.

https://library.hungaricana.hu/hu/view/OGYK_RT_1933/?pg=2397\&layout=s

257.000/1928. B.M. “A m. kir. belügyminiszter 1928. évi 257.000. számú körrendelete, a kóborcigányok hatékonyabb megrendszabályozásáról és újabb adatgyüjtés elrendelésérôl” [The Hungarian royal minister of the interior's circular decree of the year 1928, numbered 275,000, on more efficiently regulating wandering Gypsies and ordering new data collection]. Magyarországi Rendeletek Tára: Hatvankettedik évfolyam, 1928. Budapest: Magyar Kir. Belügyminisztérium, 1929, 1025-1027. https://library.hungaricana.hu/hu/view/OGYK_ RT_1928/?pg=1116\&layout=s.

Ashworth, Gregory J., Brian Graham and John E. Tunbridge. 2007. Pluralising Pasts: Heritage, Identity and Place in Multicultural Societies. London: Pluto.

Az Est. 1926. "Négyszáz hegedű muzsikája kísérte a temetőbe Kóczé Antalt" [The music of four hundred violins escorted Antal Kóczé to the cemetery]. 12 October 1926, 4.

— 1930. "Olyan a temető mint egy csatatér Radics Béla temetése után” [The cemetery is like a battlefield after Béla Radics’s funeral]. 26 February 1930, 5-6.

. 1937. "Szívünk szerelméről” [On the love of our heart]. 3 April 1937, 1.

Az Ujság. 1910. "A király udvari czigánya. Beszélgetés Berkes Bélával” [The court Gypsy of the king. A talk with Béla Berkes]. 5 January 1910, 14.

B. L. 1930. “Expozét tart a cigányok új elnöke” [The new president of the Gypsies gives an exposé]. Pesti Napló, 24 August 1930, 6.

Balla, Károly. 1862. “Emlékcsillámok” [Shimmers of memory]. Vasárnapi Ujság, 13 March 1862, 140.

Barany, George. 1969. "Hungary: From Aristocratic to Proletarian Nationalism.” In Nationalism in Eastern Europe, edited by Peter F. Sugar and Ivo J. Lederer, 259-309. Seattle: University of Washington Press.

Bársony, János. (2004) 2007. "20th Century Roma History and the Pharrajimos." In Pharrajimos: The Fate of the Roma During the Holocaust, edited by János Bársony and Ágnes Daróczi, translated by Gábor Komáromy, 23-48. New York: International Debate Education Association.

Berkes, Béla. 1943. Családi hegedü [Family violin]. Budapest: printed by the author. 
Berza, László, ed. 1982. Budapest története képekben 1493-1980. Képkatalógus [The history of Budapest in pictures 1493-1980. Image catalog], Vol. 2. Budapest: Fővárosi Szabó Ervin Könyvtár.

Bevilaqua-Borsody, Béla. 1928. “A francia romanticizmus és a Ferenc császár-kori pesti Cigánysor” [French Romanticism and the Gypsy row in Emperor Francis-era Pest] Magyar Hirlap, 14 October 1928, 8.

BFL (Budapest Főváros Levéltára [Budapest Capital City Archives]). 1937. Budapest közigazgatási térképsorozata az épületek szintszámával és az újabb utcanevekkel (1937) (The administrative map series of Budapest with the number of building floors and recent street names). 1937. MAPIRE - Historical Maps Online. Budapest: Arcanum Adatbázis Kft. https://mapire.eu/en/map/budapest-1937/.

Budai Napló. 1937. "Világvárosi látványosság a szigeti Casino" [The Casino on the island is a metropolitan spectacle]. 27 May 1937, 4.

Budapesti Hirlap. 1885a. "Rácz Pali meghalt" [Pali Rácz died]. 31 January 1885, 3-4.

—. 1885b. “Rácz Pali temetése” [Pali Rácz’s funeral]. 1 February 1885, 3-4.

—. 1890a. "Nagy cigányhangverseny” [Great Gypsy concert]. 22 March 1890, 9.

—. 1890b. “Rácz Pali siremlékét ...” [Pali Rácz’s tomb monument ...]. Untitled news item. 31 October 1890, 6.

—. 1897. “Cigánygyülés” [Gypsy assembly]. 25 January 1897, 4.

—. 1927a. "Bihari János emlékezetének évszázados ünneplése" [The centennial celebration of János Bihari’s memory]. 3 April 1927, 14.

—. 1927b. "Bihari János emlékezete" [János Bihari’s memory]. 23 April 1927, 11.

—.1928a. "Autóutat építenek a Margitszigeten a régi lóvasút helyén" [Road for car traffic to replace old horse tram line on Margaret Island]. 11 April 1928, 9.

_ 1928b. "Bihari-szobor a Margitszigeten” [Bihari statue on Margaret Island]. 2 September 1928, 16.

—. 1930. "Egy müncheni kávéházban inzultálták a magyar zenekart” [Hungarian band insulted at a Münich café]. 4 December 1930, 9.

— 1936. “Kesergő a Mátyás téri cigánysoron. Négyezer állásnélküli zenész keserves élete” [Lament on the Gypsy row of Mátyás Square. The bitter life of 4,000 jobless musicians]. 9 August 1936, 8.

—. 1937a. "Elhalasztották a nemzetközi cigánytanulmányi kongresszust" [International Gypsy lore congress postponed]. 4 September 1937, 8.

— 1937b. "Magyar cigányzenészek ünnepe az Országzászlónál” [Feast of Hungarian Gypsy musicians by the Country Flag]. 8 May 1937, 6.

_. 1937c. "Gipsy-ológiai világkongresszus lesz Budapesten” [Gipsy-ology world congress to be held in Budapest]. 7 July 1937, 2.

—. 1937d. "Szegénykatasztert állítanak fel a budapesti cigányok munkanélküli kollégáikról” [Budapest Gypsies set up a poor registry of their unemployed colleagues]. 27 July 1937, 2.

Csapó, Csaba. 2018. "Híres cigányprímások” [Famous Gypsy bandleaders]. Heritage walk at Fiume Road National Graveyard, Budapest, provided by Nemzeti Örökség Intézete (National Heritage Institute, Hungary), 28 July 2018 .

Csemer, Géza. 1998. “A prímás árvalánya...” [The bandleader’s orphaned daughter...]. Barátság, 5, No. 6 (December 15): $2327-2328$. 
D. I. 1928. "Egyórás vitám a cigányok elnökével a dzseszbendről, a cigányok kenyeréről és a magyar nóta sorsáról.” [My hour-long debate with the president of the Gypsies on the jazz band, the wages of Gypsies and the fate of Hungarian song]. Magyarság, 2 February 1928, 8.

De Oliver, Miguel. 2001. "Multicultural Consumerism and Racial Hierarchy: A Case Study of Market Culture and the Structural Harmonization of Contradictory Doctrines." Antipode 33, No. 2 (March): 228-259. https://doi. org/10.1111/1467-8330.00182.

Esti Kurir. 1928. “A szinügyi bizottság a jazz- és cigányzene harcában” [The theatrical committee in the struggle between jazz and Gypsy music]. 5 June 1928, 5.

F. B. 1935. "Dankó Pista kontra Madách Imre” [Pista Dankó versus Imre Madách]. 8 Órai Ujság, January 31, $1935,4$.

Farkas, Imre. 1940. “Magyari Imre” [Imre Magyari]. Képes Vasárnap, 5 May 1940, 12.

Fortepan / MKHL (Magyar Királyi Honvéd Légierő [Royal Hungarian Air Force]). 1944. Budapest légifotók (1944) [Aerial photographs of Budapest (1944)]. Photograph. MAPIRE - Historical Maps Online. https://mapire.eu/en/map/bp1944

Fővárosi Közlöny. 1923. "A VIII. kerületi Köztemetö-út új elnevezése” [The new name of Köztemető Road in the eighth district]. 8 June 1923, 1350.

—. 1928. “A középítési bizottság ülése 1928. június 12-én” [The meeting of the public construction committee on June 12, 1928]. 26 June 1928, 1771-1773.

Fővárosi Lapok. 1889. "A cigányprímás síremléke” [The tomb monument of the Gypsy bandleader]. 20 October $1889,2140$.

—. 1895. “A vén czigány temetése” [The old Gypsy’s funeral]. 6 November 1895, 2842.

Friss Ujság. 1927. “Bihari Jánosnak, a Rákóczi-induló szerzőjének emlékét országszerte megünneplik” [The memory of Rákóczi March author János Bihari is celebrated nationwide]. 22 April 1927, 5.

—. 1937. "Bihari emlékérmet alapítanak a cigányzenészek" [Gypsy musicians introduce a Bihari memorial medallion]. 4 August 1937, 4.

Gál, Imre. 1936. “Eltanácsolták Németországból a 24 tagu magyar rajkó-zenekart, mert kiderült, hogy - nem árják” [24-member Hungarian Romani youth orchestra expelled from Germany because it turned out - they are not Aryan]. Esti Kurir, 12 April 1936, 9.

Goda, Gertrud. 1993. Izsó Miklós, 1831-1875 [Miklós Izsó, 1831-1875]. Miskolc: Herman Ottó Museum.

Gosztonyi, Lajos. 1935. "A vén cigány fejfájára. Utolsó beszélgetés az öreg Berkes Bélával a régi walesi hercegről, Rudolf trónörökösről és a békebeli királyokról” [For the headstone of the old Gypsy. A last talk with Béla Berkes Sr. on the old Prince of Wales, Archduke Rudolf and erstwhile kings]. Magyar Hirlap, 24 February $1935,10$.

Graham, Brian, Gregory J. Ashworth and John E. Tunbridge. 2000. A Geography of Heritage: Power, Culture and Economy. London: Arnold.

Gy. S. 1930. “Bura Károly cigányprímás 30 éves jubileuma” [Gypsy bandleader Károly Bura’s 30-year jubilee]. Ujság, March 25, 1930.

Hajnáczky, Tamás. 2019. “Cigányzenészek harca a két világháború közötti Magyarországon” [The struggle of Gypsy musicians in interwar Hungary]. In Magyar Cigányzenészek Országos Egyesülete. Cigányzenészek harca a két világháború közötti Magyarországon [National Association of Hungarian Gypsy Musicians. The struggle of Gypsy musicians in interwar Hungary], edited by Tamás Hajnáczky, 17-69. Budapest: Gondolat. 
Harrer, Ferenc. 1941. A Fövárosi Közmunkák Tanácsa 1930-1940 [The Board of Public Works of the Capital City 1930-1940]. Budapest: Athenaeum.

Hegyi, Aranka. 1905. “Önéletrajz” [Autobiography]. Tolnai Világlapja, 5 November 1905, 1774-1777.

Hooker, Lynn M. 2013. Redefining Hungarian Music from Liszt to Bartók. Oxford: Oxford University Press.

HU BFL II.1.a. A Fövárosi Közmunkák Tanácsa tanácsülési és bizottsági jegyzőkönyvei (1870-1948) [Board and committee meeting notes of the Board of Public Works of the Capital City]. Vol. 60 (1929-1930).

- Vol. 63 (1934).

- Vol. 65 (1936).

- Vol. 66 (1937).

- Vol. 68 (1939).

HU BFL IV.1407.b. Budapest Székesfóváros Tanácsának iratai [Records of the Council of the Royal Seat and Capital City of Budapest]. 21063/925. A IX. kerületi elöljáróság jelentése [Report by the Magistrate’s Office of the Ninth District]. 2 October 1925.

HU BFL IV.1409.c. Budapest Székesföváros Polgármesterének iratai, 1873-1950. Polgármesteri Ügyosztályok Központi Irattára, 1930-1950 [Records of the Mayor of the Royal Seat and Capital City of Budapest, 1873-1950. Central Archive of the Mayor's Departments, 1930-1950]. 134.790/1930-IV. Letter from Marci Banda, the president of the National Association of Hungarian Gypsy Musicians, to the mayor of Budapest, 25 August 1930.

HU BFL IV.1478.a. Budapest Székesföváros IX. Kerületi Elöljáróságának iratai (1873-1992). [Records of the Magistrate's Office of the Ninth District of the Royal Seat and Capital City of Budapest (1873-1992)]. 10441/922. Károly Berkós trade licence, 16 April 1922.

HU BFL XV.17.d.322.a. Fövárosi Közmunkák Tanácsa tervei és térképei (1870-1948). Épülettervek és térképek [Plans and maps of the Board of Public Works of the Capital City (1870-1948). Building plans and maps]. 57.c. A Szent Margitsziget általános elrendezési terve [The general arrangement plan of Saint Margaret Island]. Board of Public Works of the Capital City, Technical department, 29 April 1916.

https://maps.hungaricana.hu/en/BFLTerkeptar/3515

- 57. b. Szent-Margitsziget helyszinrajza [Site plan of Saint Margaret Island]. Board of Public Works of the Capital City, 1926. https://maps.hungaricana.hu/en/BFLTerkeptar/3521

HU BFL XV.17.d.329. Építési Ügyösztályok Tervtára (1873-2006) [Plan Collection of the Building Departments (1873-2006)]. 36961. Építési engedélyezési tervdokumentáció [Building permit drawings]. Ground floor plan by architect Mór Kallina, 13 April 1909.

Isoz, Kálmán. 1928. Bihari és a katonafogdosás [Bihari and soldier recruitment]. Zenei Szemle 12, No. 5-7 (JuneAugust): $122-123$.

Járosi, Jenő. 1930. "A magyar nóta meg a cigány" [Hungarian song and the Gypsy]. Napkelet 8, No. 4 (April 1): 414-418.

K. K. 1934. “A görcs álljon már az egész veszekedésbe! Beszélgetés Bura Károly cigányprímással, akit beteggé tett a rádióháború" [Damn the whole quarrel! A talk with Gypsy bandleader Károly Bura, whose health is broken down by the radio war]. Az Est, 7 March 1934, 7.

Kallós, János, ed. 1937. Gazdasági, pénzügyi és tözsdei kompasz 1937-1938 évre [Economic, financial and bourse compass for 1937-1938]. Vols. 3-4. Budapest: Pesti Tözsde. 
Kaposi, Pál. 1941. “Cigányok központi nyilvántartása” [Central registration of Gypsies]. Csendőrségi Lapok, 15 May $1941,325-327$.

Karsai, László. 1991. “Cigány katonai munkaszázadok Magyarországon 1944-1945-ben” [Gypsy military labor units in Hungary in 1944-1945]. Hadtörténeti Közlemények 104 (2): 157-166.

Kellér, Dezső. 1926. “Cigányvicclap” [Gypsy satirical paper]. Szinházi Élet, 24 January 1926, 26-27.

Kenyeres, Nándor. "Vándorol egy szobor...” [A statue wanders...]. Ujság, 28 July 1937, 7.

Kis Ujság. 1937a. “Bihary János ünnepség a Szent Margitszigeten” [János Bihary celebration on Saint Margaret Island]. 23 April 1937, 6.

—. 1937b. “Az Országos Rákóczi Szövetség ...” [The National Rákóczi Association ...]. Untitled news item. 27 April 1937, 6.

Klösz György és Fia. 1930? Szent-Margitsziget [Saint Margaret Island]. 1:12,000 scale, 9×29 cm. Hadtörténeti Intézet és Múzeum (Institute and Museum of Military History), Budapest. https://maps.hungaricana.hu/en/HTITerkeptar/36617

Kolcov, Michail [Mikhail Koltsov]. 1928. “Ahogy egy orosz kommunista látja a mai Magyarországot” [As a Russian communist sees today’s Hungary]. Translated by János Balogh. Uj Elöre, 16 January 1928, 6.

Kovács, Ákos. 2005. “Musica Pannonica” 2000, June 2005, 21-42. http://ketezer.hu/2005/06/musica-pannonica

Krúdy, Gyula. (1926) 1971. "A prímás" [The bandleader]. In Pesten lakott egy fuvolás [A flutist used to live in Pest], edited by Zsuzsa Krúdy, 92-98. Budapest: Zenemükiadó.

. (1930) 1971. "Szeretni kell tudni a nótának, mint a lánynak. (Két prímásról)” [The song has to know how to love, like a girl. (On two bandleaders)]. In Pesten lakott egy fuvolás [A flutist used to live in Pest], edited by Zsuzsa Krúdy, 139-151. Budapest: Zeneműkiadó.

Kun, Andor. 1927. “Bihari” [Bihari]. Magyar Cigányzenészek Lapja, 15 May 1927, 1-2.

Lázár, István. 1926. “'A magyar nóta a leghatalmasabb irredenta fegyver!' Interjú Brassói Kozák Gáborral, a cigányzenészek elnökével” ["Hungarian song is the greatest irredentist weapon!” Interview with Gábor Brassói Kozák, the president of Gypsy musicians]. Pesti Hirlap, 30 July 1926, 9.

Liber, Endre. 1934. Budapest szobrai és emléktáblái [The statues and memorial plaques of Budapest]. Budapest: Budapest Székesfóváros Statisztikai Kiadóhivatala.

Lloyd Könyvek Kiadóvállalat. 1930? Szent Margitsziget [Saint Margaret Island]. 1:12,000 scale, $10.5 \times 27 \mathrm{~cm}$. Hadtörténeti Intézet és Múzeum (Institute and Museum of Military History), Budapest. https://maps.hungaricana.hu/en/HTITerkeptar/36619

Loya, Shay. 2011. Liszt's Transcultural Modernism and the Hungarian-Gypsy Tradition. Rochester: University of Rochester Press.

Lukács, István. 1929. "Saját autóján érkezett Budapestre 'a kis Berkes” ["Little Berkes” arrived to Budapest in his own car]. Magyar Hirlap, 19 April 1929, 5.

Magyar Cigányzenészek Lapja. 1927. “Ne bántsd a cigányt!” [Don’t offend the Gypsy!]. 15 April 1927, 7-8.

. 1928. “Cigányzene a Margitszigeten” [Gypsy music on Margaret Island]. 15 May 1928, 7.

. 1930. “Durva támadás a magyar cígányzenészség ellen” [Rude attack on Hungarian Gypsy musicians]. 18 March 1930, 5. 
Magyar Czigányzenészek Lapja. 1908a. “A Czigányzenészek nyugdijegyesülete” [The pension association of Gypsy musicians]. 1 September 1908, 3-4.

_. 1908b. "Hangverseny" [Concert]. 1 May 1908, 5.

—. 1908c. "Radics Béla a Magyar Czigányzenészek Egyesületéről” [Béla Radics on the Association of Hungarian Gypsy Musicians]. 15 August 1908, 5.

_. 1909. “Czigányzenészek bálja Budapesten” [Ball of Gypsy musicians in Budapest]. 1 February 1909, 4.

Magyar, Erzsébet. 2004. “Kertek, parkok Buda-Pest társaséletében a 19. században. A Margitsziget” [Gardens, parks in the social life of Buda-Pest in the nineteenth century. Margaret Island]. Budapesti Negyed 12, No. 4 (Winter): 136-164.

Magyar Film Iroda Rt. 1926. Magyar Híradó, episode 148, "Radics Béla, a jubiláló cigányprímás 40 éve hegedül” [Béla Radics, the jubilee celebrating Gypsy bandleader has played the violin for 40 years]. December 1926. Video on Filmhíradók Online, 0:48 min. https://filmhiradokonline.hu/watch.php?id=8600

_ 1928. Magyar Híradó, episode 243, “Bihari János szobrának leleplezése a Margitszigeten” [The inauguration of János Bihari’s statue on Margaret Island]. October 1928. Video on Filmhíradók Online, 0:45 min. http://filmhiradokonline.hu/watch.php?id=8990

_ 1930. Magyar Híradó, 314, "Radics Béla, a váratlanul elhunyt híres cigányprímás temetése" [Unexpectedly deceased Gypsy bandleader Béla Radics’s funeral]. February 1930. Video on Filmhíradók Online, 0:38 min. https://filmhiradokonline.hu/watch.php?id=9345

Magyar Közgazdaság. 1936. “Gellér Mihály kormányfötanácsos” [Mihály Gellér appointed senior government counselor]. 27 August 1936, 6.

Magyar Országos Tudósitó. 1930a. “A cigányzenészek panasza a cigány fajtának a megsértése miatt” [The complaint of Gypsy musicians for offending the Gypsy kind]. 30 October 1930, 350.

—_ 1930b. "Két óra hosszán át tartó veszekedés után Bura Károly elnök feloszlatta a cigányzenészek egyesületének mai közgyűlését, amely egyhangú bizalmat szavazott Ilovszky Jánosnak” [After a two-hour row, president Károly Bura dissolved today's general assembly of the association of Gypsy musicians, which uniformly expressed confidence to János Ilovszky]. 5 August 1930.

—_. 1930c. "Mintegy százezer ember jelenlétében temették el hétfőn délután Radics Béla cigányprímást" [Gypsy bandleader Béla Radics's funeral, attended by some 100,000, took place on Monday afternoon]. 24 February 1930, 156-157.

—. 1930d. "Radics Béla temetése" [Béla Radics’s funeral]. 22 February 1930, 130.

_. 1939. "A közigazgatási bizottság ülése" [The meeting of the committee of public administration]. 30 August $1939,108-111$.

—. 1940. "Tompa Mihály szobrának ünnepélyes felavatása” [The ceremonial inauguration of Mihály Tompa’s statue]. 28 September 1940, 137-140.

Magyarország. 1897. “Hegyi Aranka gyásza” [Aranka Hegyi’s mourning]. 31 March 1897, 7-8.

. 1926. "Elnémult a vajda... Háromszáz cigány hegedüszavával sokezer ember búcsúzott Kozák Gábortól" [The voivode went silent... Many thousands said farewell to Gábor Kozák to the voice of 300 Gypsies’ violins]. 28 December 1926, 4.

_ 1928. "A magyar zene védelmét kérik a belügyminisztertől a cigányzenészek" [Gypsy musicians ask the minister of interior to protect Hungarian music]. 20 March 1928, 8. 
—. 1934. "Új otthont kaptak az állástalan cigányzenészek" [New care home granted to jobless Gypsy musicians]. 14 December 1934, 4.

. 1938a. "Forradalom tört ki Dankó Pista ellen a Dankó Pista utcában" [Revolution against Pista Dankó in Pista Dankó Street]. 19 May 1938, 11.

—. 1938b. “"Vigyázzunk, nehogy megkapjuk a cigányoktól a vándorlási lázat” [We have to be careful not to catch the fever for wandering from the Gypsies]. 6 July 1938, 5.

Magyarság. 1934. “Ha így május felé az ember Dél-Franciaországban jár ...” [If around this time in May one happens to be in southern France ...]. Untitled news item. 22 April 1934, 8-9.

. 1936a. "Budapesten tartják a cigánykérdés tudósainak első kongresszusát" [Budapest to host the first congress of the scholars of the Gypsy question]. 16 July 1936, 4.

—. 1936b. “A pécskai cigánysoron... Válságban van Pécsett a cigánymuzsika - Száz család, közel ötszáz ember teng a legnagyobb nyomorúságban” [On the Gypsy row of Pécska... Gypsy music in crisis in Pécs - A 100 families, nearly 500 vegetate in greatest misery]. 19 July 1936, 6.

Major, Ervin. 1928. “Bihari János” [János Bihari]. Zenei Szemle 12, No. 1-2 (January-February): 5-27.

Malonyai, János. “A pesti cigánysoron” [On the Gypsy row of Pest]. Új Barázda, 25 September 1921, 5.

Markó, Miklós. (1896) 2006. Czigányzenészek Albuma [Album of Gypsy musicians]. Budapest: Fekete Sas.

Martínez-Echazábal, Lourdes. 1998. "Mestizaje and the Discourse of National/Cultural Identity in Latin America, 1845-1959." Latin American Perspectives 25, No. 3 (May): 21-42. https://doi.org/10.1177/0094582X9802500302

Mátray, Gábor. (1854) 1984. “Bihari János magyar népzenész életrajza” [Hungarian folk musician János Bihari’s biography]. In A Muzsikának Közönséges Története és egyéb írások [The Common History of Music and other writings], edited by György Gábry, 288-304. Budapest: Magvető.

MCOE (Magyar Cigányzenészek Országos Egyesülete [National Association of Hungarian Gypsy Musicians]). 1923. Magyar Cigányzenészek Országos Egyesülete Módositott Alapszabályai [The modified statutes of the National Association of Hungarian Gypsy Musicians]. Budapest: MCOE.

—. 1943. Magyar Cigányzenészek Országos Egyesülete Alapszabályai [The statutes of the National Association of Hungarian Gypsy Musicians]. Budapest: MCOE.

MCOSz (Magyar Cigányzenészek Országos Szövetsége [National Alliance of Hungarian Gypsy Musicians]). 1936. A Magyar Cigányzenészek Országos Szövetségének Alapszabályai [The statutes of the National Alliance of Hungarian Gypsy Musicians]. Budapest: MCOSz.

Móra, Ferenc. (1912a) 1964. "A cigányszobor” [The Gypsy statue]. In Szegedi tulipános láda [Szeged tulip chest], edited by Imre Paku, 76-78. Budapest: Magvető.

—_. [Csipke, pseud.]. 1912b. “Pósa Bácsi” [Uncle Pósa]. Szegedi Napló, 20 October 1912. n.p.

__. (1922) 1964. “Dankó Pista” [Pista Dankó]. In Szegedi tulipános láda [Szeged tulip chest], edited by Imre Paku, 182-189. Budapest: Magvető.

Nagy, Ildikó. 1990. “Társadalom és művészet: a historizmus szobrászai” [Society and art: The sculptors of historicism]. Müvészettörténeti Értesitő 39 (1-2): 1-21.

_ 2004. "A pesti Vigadó szobrai és szobrászai” [The statues and sculptors of the Vigadó in Pest]. In Romantikus kastély. Tanulmányok Komárik Dénes tiszteletére [Romantic castle: Papers in honor of Dénes Komárik], edited by Ferenc Vadas, 345-355. Budapest: Hild-Ybl Alapítvány. 
Nemzeti Ujjág. 1927. "Gyászistentisztelet Bihary János születésének századik évfordulóján” [Memorial service on János Bihary’s birth centenary]. 27 April 1927, 10.

Népszava. 1933. "A román cigánykongresszus" [The Romanian Gypsy congress]. 25 October 1933, 9.

. 1934. A romániai cigánykongresszus résztvevőinek egyik csoportja [A group of participants at the Romanian Gypsy congress]. Photograph. 16 September 1934, 10.

_ . 1940. "Magyari Imre halála ...” [Imre Magyari’s death ...]. Untitled news item. 30 April 1940, 4.

Nora, Pierre. 1989. “Between Memory and History: Les Lieux de Mémoire." Translated by Marc Roudebush. Representations 26 (Spring): 7-24. https://doi.org/10.2307/2928520

Nyírvidék. 1927. "Radics Béla, a signum laudis-szal kitüntetett világhírű cigányprímás elmeséli régi emlékeit a

'Nyírvidék' munkatársának” [Béla Radics, the world-famous Gypsy bandleader honored with signum laudis tells his old memories to the reporter of Nyírvidék]. 28 September 1927, 4.

Pálos, Ödön. 1927. “Bihary János” [János Bihary]. Nemzeti Ujság, 22 April 1927, 3-4.

Ormos, László. 1925. “Öreg Kóczé Antal elsiratja halott fiát” [Antal Kóczé Sr. mourns his dead son]. Ujság, 5 September 1925, 4.

Papastergiadis, Nikos. 2005. "Hybridity and Ambivalence. Places and Flows in Contemporary Art and Culture." Theory, Culture \& Society 22, No. 4 (August): 39-64. https://doi.org/10.1177/0263276405054990

Pesti Hirlap. 1908. “A cigánymuzsikusok mozgalma” [The movement of Gypsy musicians]. 3 February 1908, 12.

—. 1922. “Cigányzenészek a 'jazz band’-ek ellen” [Gypsy musicians against “jazz bands”]. 8 January 1922, 12.

. 1932. "Leleplezték Radics Béla síremlékét” [Béla Radics's tomb monument has been inaugurated]. 6 September 1932, 7.

—. 1937a. "A magyar cigányzenészség ötszázéves jubileuma” [The 500-year jubilee of Hungarian Gypsy musicians]. 14 March 1937, 18.

_. 1937b. “Bihary-ünnepség a Margitszigeten” [Bihary fest on Margaret Island]. 23 April 1937, 18.

_. 1943. “Meghalt 36-ik Rácz Laci” [Laci Rácz the 36th died]. 11 May 1943, 298.

Pesti Napló. 1900. "Egy híres cigány halála" [The death of a famous Gypsy]. 30 September 1900, 7.

_. 1908a. "Blaha Lujza és a cigányok” [Lujza Blaha and the Gypsies]. 9 April 1908, 11.

—. 1908b. "Cigány-gyülés” [Gypsy assembly]. 23 February 1908, 15.

—. 1908c. “Ötszáz cigányzenész hangversenye” [A concert of 500 Gypsies]. 12 May 1908, 16.

—. 1912. "A cigánybörze megszünt” [The Gypsy fair ceased]. 18 June 1912, 8.

—_. 1926. “Eltemették Kozák Gábort” [Gábor Kozák has been laid to rest]. 28 December 1926, 13.

_. 1927. "Emléket kap Bihari cigányprímás" [Gypsy bandleader Bihari gets commemorative sign]. 15 April $1927,13$.

_. 1934. "Eltemették Bura Károlyt" [Károly Bura has been laid to rest]. 5 June 1934, 11.

. 1937a. "A cigány a legelső árja faj Európában” [The Gypsy is the very first Aryan race in Europe]. 7 July 1937, 13.

1937b. “A magyar cigányzenészek ötszázéves jubileuma” [The 500-year jubilee of Hungarian Gypsy musicians]. 14 March 1937, 18. 
—.1937c. “Megállapították a cigányság országos jubiláris ünnepségeinek programját” [The program of the national jubilee celebrations of the Gypsy people has been laid down]. 2 April 1937, 13.

. 1937d. “A Rákóczi Szövetség Bihary-ünnepe” [The Bihary fest of the Rákóczi Association]. 23 April 1937, 12.

Picker, Giovanni. 2017. Racial Cities: Governance and the Segregation of Romani People in Urban Europe. London and New York: Routledge.

Piotrowska, Anna G. 2013. Gypsy Music in European Culture: From the Late Eighteenth to the Early Twentieth Centuries. Boston: Northeastern University Press.

Pogány, Béla. 1934. “Pista, vagy István?” [Pista, or István?] Budapesti Hirlap, 21 November 1934, 7.

Porzsolt, Kálmán. 1907. “A mi cigány hírünk” [Our Gypsy reputation]. Pesti Hirlap, 6 August 1907, 9-10.

Purcsi Barna, Gyula. 2004. “Cigányellenes javaslatok és razziák Pest megyében Endre László alispánsága idején (1928, 1939-1944)" [Anti-Gypsy initiatives and raids in Pest County under deputy-lieutenant László Endre (1928, 1939-1944)]. In Pharrajimos. Romák sorsa a nácizmus idején [Pharrajimos: The fate of Roma under Nazism], edited by János Bársony and Ágnes Daróczi, 35-59. Budapest: l’Harmattan.

_ (2004) 2007. "Anti-Gypsy Initiatives and Raids in Pest County under Deputy-Lieutenant László Endre (1928, 1939-1944)." In Pharrajimos: The Fate of the Roma During the Holocaust, edited by János Bársony, and Ágnes Daróczi, translated by Gábor Komáromy, 49-86. New York: International Debate Education Association.

Rexa, Dezső. 1940. Margitsziget [Margaret Island]. Budapest: Officina.

S. A. 1903. "A pesti cigány. Budapest etnográfiájához" [The Gypsy of Pest. On the ethnography of Budapest]. Pesti Napló, 9 March 1903, 10.

Sági, Pál. 1928. “Jazz muzsikára akarnak áttérni a pesti cigányok, mert nem kapnak szerződést a szórakozóhelyeken” [Gypsies of Pest want to switch to jazz in lack of performance contracts]. Budapesti Hirlap, 20 March 1928, 8-9.

Sárosi, Bálint. 1971. Cigányzene... [Gypsy music...]. Budapest: Gondolat.

—. 2002. Bihari János [János Bihari]. Budapest: Mágus.

Sebestyén, Gábor. 1829. “Csermák’ emléke” [Csermák’s memory]. Felső Magyar-Országi Minerva 5 (1829): 289-290.

Sibley, David. 1995. Geographies of Exclusion: Society and Difference in the West. London: Routledge.

Sipos, András. 2005. "A hivatalos várospropaganda Budapest-képe a két világháború között” [The image of Budapest in the official city propaganda between the two world wars]. In Terek és szövegek. Ujjabb perspektívák a városkutatásban [Spaces and texts. New perspectives in urban research], edited by Tímea N. Kovács, Gábor Böhm, and Tibor Mester, 155-161. Budapest: Kijárat.

Sólymossy, Elek. 1880. “Színházi csevegés” [Theater chat]. Esztergom és Vidéke, 26 September 1880, n.p.

Somogyi, Vilmos. 1928. "A cigányzene és a jazz élet-halál harca” (The life-and-death match of Gypsy music and jazz]. Esti Kurir, 21 March 1928, 7.

Stób, Zoltán. 1926. "Cigányzenészek harca a néger muzsika ellen” [Gypsy musicians’ fight against Negro music]. Friss Ujság, 6 October 1926, 2.

Sturcz, János. 1983. “A Kerepesi és Farkasréti temető újabb síremlékeiről” [On the late tomb monuments of Kerepesi and Farkasréti cemeteries]. Ars Hungarica 38 (1): 187-198. 
Sugar, Peter F. 1969. "External and Domestic Roots of Eastern European Nationalism." In Nationalism in Eastern Europe, edited by Peter F. Sugar and Ivo J. Lederer, 3-54. Seattle: University of Washington Press.

Sz. N. 1935. “Cserebogár, sárga cserebogár. Magyari Imre a harmadik magyar cigány, aki legfelsőbb helyről kitüntetést kapott” [Maybug, yellow maybug. Imre Magyari is the third Hungarian Gypsy to have been awarded by the highest authority]. Ujság, 22 August 1935, 5.

Szemere, Pál. 1824. "Bihari János életrajza” [János Bihari’s biography], Pest, July 7, 1824. B/14 Szemere Pál levéltára [Pál Szemere’s archives], Vol. 8, 373-376. A Dunamelléki Református Egyházkerület Ráday Levéltára (Ráday Archives of the Danubian Reformed Church District), Budapest, Hungary.

Szegedi Napló. 1912. "A cigány-szobor leleplezési ünnepségei” [The inauguration ceremonies of the Gypsy statue]. 22 October 1912, 3-4.

T. 1924. “A prímás" [The bandleader]. Világ, 11 March 1924, 4.

Telkes, Simon. 1898. Hogy magyarositsuk a vezetékneveket? [How to Magyarize surnames?], Third edition. Budapest: Pesti Könyvnyomda Rt.

Tinódi. 1928. "Bihari János emlékezetének százados ünneplése” [The centennial celebration of János Bihari’s memory]. Ország-Világ, 11-18 November 1928, 250-252.

Tolnai Világlapja. 1925. "Kóczé Lajos, Kóczé Antal cigányprímás fiának temetése" [The funeral of Lajos Kóczé, Gypsy bandleader Antal Kóczés son]. 16 September 1925, 11.

—. 1930. "A magyar nóta ünnepe" [The feast of Hungarian song]. 4 June 1930, 6.

Tompa, Mihály. (1849) 2003. "Más a császár katonája, más a haza katonája” [The emperor’s soldier and the homeland’s soldier are not alike]. In Tompa Mihály összes költeménye [Mihály Tompa’s complete poetry], 581-584. Budapest: Hungarian Electronic Library. http://mek.oszk.hu/01100/01101

Tóth, Vilmos. 1999. “A Kerepesi úti temető másfél évszázada” [The one and a half century of Kerepesi Road Cemetery]. Budapesti Negyed 24, No. 1 (Spring): 3-126.

Trencsényi, Balázs. 2012. The Politics of National Character: A Study in Interwar East European Thought. London: Routledge.

Ujság. 1926. "Eltemették Kozák Gábort, a cigányok elnökét” [Gábor Kozák, the president of the Gypsies, has been laid to rest]. 28 December 1926, 8.

— 1927a. "Bihari János cigányprimás halálának százéves évfordulója” [The centenary of Gypsy bandleader János Bihari’s death]. 14 April 1927, 9.

——. 1927b. "Bihari Jánosnak, a Rákóczi-induló szerzőjének emlékét országszerte megünneplik" [The memory of Rákóczi March author János Bihari is celebrated nationwide]. 22 April 1927, 8.

—. 1927c. “Öreg Magyari Imre kitüntetése” [Imre Magyari Sr.s award]. 11 May 1927, 8.

—.1927d. "Olyan a jazz-band mint a járvány - küzdeni kell ellene”' [The jazz band is like a plague - it has to be fought against]. 22 September 1927, 8 .

—. 1927e. "Katonazenésznek nevelik fiaikat a cigányzenészek, akik igy védekeznek a jazz ellen...” [Gypsy musicians raise their sons to be army musicians, in defense against jazz...]. 12 November 1927, 9.

__. 1929a. "Elnököt választanak a cigányok” [The Gypsies elect a president]. 2 January 1929, 8.

_. 1929b. "Iskolát nyitottak a magyar cigányzenészek" [Hungarian Gypsy musicians opened a school]. 21 September 1929, 5. 
— 1929c. “Zeneiskolában fognak tanulni a fiatal cigányok. Bura Károly, a cigányok elnöke - a jazz-ről” [Young Gypsies will learn at music school. Károly Bura, president of Gypsies - on jazz]. 6 March 1929, 2.

. 1937a. "Bucsubeszélgetés Magyari Imre cigányprimással” [Farewell conversation with Gypsy bandleader Imre Magyari]. 26 September 1937, 12.

1937b. "Uj forrás a Margitszigeten" [New fountain on Margaret Island]. 14 July 1937, 8.

1943. "Meghalt 36. Rácz Laci, a cigányok koronázatlan királya” [Laci Rácz the 36th, the uncrowned king of the Gypsies, died]. 7 May 1943, 4.

Urmánczy, Nándor. 1928. “A cimbalmos” [The cimbalom player]. Pesti Hirlap, 13 January 1928, 1-2.

Vari, Alexander. 2012. “Re-territorializing the 'Guilty City’: Nationalist and Right-wing Attempts to Nationalize Budapest during the Interwar Period.” Journal of Contemporary History 47, No. 4 (October): 709-33. https://doi.org/10.1177/0022009412451288

Városok Lapja. 1937. “Ötszázéves jubileumukat ünneplik a magyar cigányzenészek” [Hungarian Gypsy musicians celebrate their 500-year jubilee]. 15 April 1937, 244.

Vasárnapi Ujság. 1885. “Rácz Pali síremléke” [Pali Rácz’s tomb monument]. Vol 32 (1885): 133.

Wiley, Eric. 2005. "Romani Performance and Heritage Tourism: The Pilgrimage of the Gypsies at Les SaintesMaries-de-la-Mer." The Drama Review 49, No. 2 (Summer): 135-158. 